Studia Anglica Posnaniensia 50/4, 2015

doi: 10.1515/stap-2015-0032

\title{
ON SPECIFICATION PREDICATION AND THE DERIVATION OF COPULAR TO-CLAUSES IN POLISH
}

\author{
PRZEMYSEAW TAJSNER*
}

Faculty of English, Adam Mickiewicz University in Poznań

\begin{abstract}
The paper offers a consistently derivational account of Polish predicational and specificational copular clauses with the occurrence of a particle to instead of a verbal copula być ('be'). The particle to is given the status of a predicative head with the potential of designating a phrase in its c-command domain as a specification predicate. Such a phrase is then interpreted as the focus at the C-I interface. Thus, a view is promoted in which the focus, a category of information structure, is not directly coded in narrow syntax, but is rather an interpretive outcome of a more general syntactic relation, referred to as Specification Predication. This view has been inspired by Kiss's $(2006,2010)$ idea that focusing is predication but it substantially differs from her approach. The analysis is limited to copular-to clauses, but it is suggested to have a potential for the account of two more syntactic types with the occurrence of the particle to, namely, so-called to-clefts, and topic-to sentences.

The proposal advanced in the paper is confronted with three earlier accounts dealing with copular-to clauses, and is shown to avoid some empirical and conceptual problems they have posed. It is shown how the derivation of copular-to clauses proceeds through a sequence of minimal and well-defined steps starting from the formation of an array of two nominal phrases, through a Small Clause stage to a Specification Predicative Phrase. Couched in the recent minimalist framework, the analysis specifically dwells on the theoretical advancements determining the nature of syntactic derivations, such as Hornstein's (2009) distinctions between operations Concatenate, Merge and Label, Moro's (2000, 2008) idea of Spontaneous Symmetry Breaking or Chomsky's (2013) view of Labeling.
\end{abstract}

Keywords: copula, copular clauses, predication, specification, focus, derivation

Corresponding author: Przemysław Tajsner (tprzemek@wa.amu.edu.pl), Faculty of English, Adam Mickiewicz University in Poznań, al. Niepodległości 4, 61-874 Poznań, Poland. 


\section{Introduction}

Polish features a copular construction in which a verbal copula is replaced by a non-verbal particle to, as in (1) below:

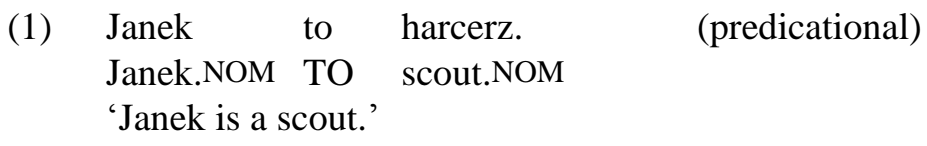

The status of the particle to has been a matter of dispute to which the present paper contributes with the hypothesis that to in (1) is a head of the Specification Predication Phrase (S-PredP) in the sense inspired by Kiss's idea that focusing is (specification) predication (Kiss 2006, 2010). As such, it selects a phrase within its c-commanding domain and designates it for a focus interpretation at the C-I interface, and, additionally, partitions a clause into topic and focus parts, as sketched in (2):

\section{(2) [PredP[TopICJanek] [[Pred to] [Focusharcerz]]]]}

The designation of a phrase for focus interpretation by to is not confined to nonverbal copular constructions. The same role can be ascribed to to occurring in two other types of constructions, referred to as to-clefts and topic-to sentences, exemplified by (3) and (4), respectively:
(3) To Janek
pomógł
starszej pani.
TO Janek.NOM.FOC help.PST.3SG.M
older.DAT lady.DAT
'It was Janek who helped an elderly lady.'
(4) Janek to pomógł starszej pani.
Janek.NOM.TOP TO help.PST.3SG.M older.DAT lady.DAT
'As for Janek, he helped an elderly lady.'

Thus, it will be argued below that while functionally to in examples (1) and (3)(4) qualifies as a focus marker, then syntactically it represents the head of the Specification Predication, following the scheme (2) across-the-board. One persuasive argument in favour of such a view is the frequently observed isomorphism of focus markers and non-verbal copulas cross-linguistically (e.g. in Sumerian (Huber 1999; Kiss 2006), Mupun (Frajzyngier 1993; Green 2007) or Hausa (Green 2007)). 
Due to space limits, although implicitly heralding a uniform account of the three syntactic types introduced above, the present paper deals only with copular-to structures leaving to-clefts and topic-to sentences for a separate study. ${ }^{1}$ The paper starts with a brief typology of copular sentences in Polish, which is followed by a discussion of the three earlier accounts of non-verbal copular sentences in Polish. Next, some problems arising from these approaches are pinpointed and a more unitary alternative is offered. This proposal owes to Kiss (2006) the central idea that focusing is predication, but modifies her approach in some important respects. The discussion ends with a summary of the advantages of the proposal and conclusions.

\section{Copular sentences in Polish}

The classical division of copular sentences proposed by Higgins (1973) is into four major types:

a. Predicational copular sentences, e.g. John is a vet.

b. Specificational copular sentences, e.g. The coldest month is January.

c. Equative copular sentences, e.g. Jorge Mario Bergoglio is Pope Francis.

d. Identificational copular sentences, e.g. This river is the Volga.

A division as above has been subjected to revisions and controversies. For example, some authors suggest that specificational and equative types should be conflated (Heycock \& Kroch 1999, Sharvit 1999). Others argue for subsuming the identificational type in the specificational category (Geist 2007) or classifying some identificational clauses as specificational and others as equative (Mikkelsen 2005a). Still others argue for finer distinctions among the types, for example, Roy (2006) postulates that a predicational class should be subdivided into characterizing and defining.

As discussed by Bondaruk (2013), Polish displays the four types distinguished by Higgins (1973), but it features some interesting idiosyncrasies, which arise from two sources: (i) the availability of two types of copulas, a verbal one być ('be'), and a non-verbal one to być (particle to+'be'), and (ii) case alternations on the phrases following the copula. Thus, either type of copula can occur in predicational copular clauses, but to być requires a nominal complement inflected for Nominative, while być needs an NP inflected for Instrumental and allows also an AP in Nominative, as illustrated in (5)-(7) below:

1 The analysis of Polish to-clefts and topic-to sentences unified with the present account of copular-to clauses is offered in a parallel paper (Tajsner forthcoming). 
(5) Janek jest harcerzem/*harcerz

Janek.NOM be.PRES.3SG scout.INST/*scout.NOM

'Janek is a scout.'

(6) Janek to (jest)

Janek.NOM to (be.PRES.3SG) scout.NOM/*scout.INST

'Janek is a scout.'

(7) Janek jest wesoły $/{ }^{*}$ wesołym

Janek.NOM be.PRES.3SG jolly.NOM/*jolly.INST

Specificational, equative and identificational copular clauses display a nonverbal to (być) copula and a Nominative nominal, but a verbal one can also sometimes occur in the latter two types, as given in (8)-(12) below:
(8) Mój kolega
to (jest)
Marek
(specificational)
my.NOM colleague.NOM
TO (be.PRES.3SG) Marek.NOM
'My colleague is Mark.'
Bondaruk (2013:137)
(9) Jorge Mario Bergoglio
to (jest)
Papież Franciszek
(equative)
Jorge Mario Bergoglio.NOM TO (be.PRES.3SG) Pope Francis. NOM
'Jorge Mario Bergoglio is Pope Francis.'

(10) $\mathrm{Ta}$ rzeka to (jest) Wołga.(identificational)

this.NOM river.NOM TO (be.PRES.3SG) Volga.NOM

'This river is the Volga.'
(11) Ty jesteś Kowalski. (equative) you.NOM be.PRES.2SG Kowalski.NOM
'You are Kowalski.'
Bondaruk (2013:136)
(12) To jest Wołga. (identificational)
this be.PRES.3SG Volga.NOM
'This is Volga.'

The concern of the present paper is not to argue for any of the proposed taxonomies of copular sentences or discuss the criteria of their classification. Instead, the interest will be confined to two types: predicational and specificational, and, what is more, the discussion will be limited mainly to these instances of predi- 
cational and specificational Polish copular sentences in which a verbal copula być is replaced by a non-verbal copula to alone, without the co-occurrence of być.

The definitions of predicational and specificational copular sentences that we adopt are Higgins' (1979). Thus, in the former, some property is ascribed to the subject referent by the expression following the copula, for example, in (13) below, the property of "being a scout" is ascribed to Janek. In the latter, a value is provided by the post-copular expression for the variable set up by the subject. In (14), the expression najzimniejszy miesiac ('coldest month') sets up a variable (there is such an $\mathrm{x}, \mathrm{x}$ month, such that $\mathrm{x}$ is the coldest) and the nominal styczeń ('January') provides a value for this variable.

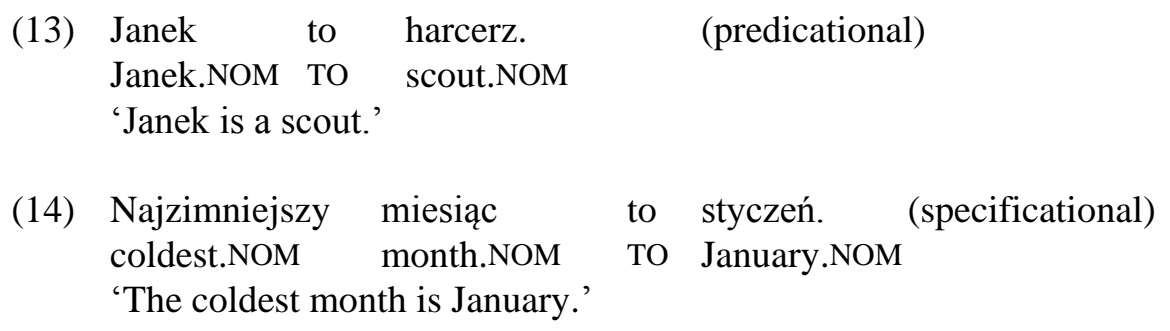

Sentences (13) and (14) have their counterparts with the verbal copula byc ('be') and Instrumental case on one of the DPs, as shown in (15) and (16):
(15) Janek
jest
harcerzem. (predicational)
Janek.NOM be.PRES.3SG scout.INST
'Janek is a scout.'
(16) Najzimniejszym miesiącem jest styczeń. (specificational) coldest.INST month.INST be.PRES.3SG January.NOM 'The coldest month is January.'

The two instances of predicational sentences in (15) and (13) are not fully synonymous. As noted by Bondaruk (2013: 214), a construction with a non-verbal copular to, unlike the one with the verbal copular być ('be'), marks "lifetime effects", so that the property predicated of Janek in (13) is permanent, while this attributed to him in (15) may only be temporary. This may be demonstrated in the exchange (17) below: ${ }^{2}$

2 For a discussion of more differences between the two types of predicational sentences see Bondaruk (2013). 
(17) A: Nasz prezydent jest naprawdę odważny!

A: 'Our president is really brave!'

B: Nic dziwnego, Bronek to harcerz!

B: 'No wonder, Bronek is a scout!'

?!Nic dziwnego, Bronek jest harcerzem!

Given the observed differences, Bondaruk (2013: 215), following Roy (2006), assigns the two types of predicational copular clauses to two subclasses: the ones with a to-copula are classified as defining, while those with a be-copula as characterizing. ${ }^{3}$ Another interesting property of the types exemplified by (13)(16) is a variance in the accessibility of inversion. While both types of sentences classified originally as specificational (with to and być ('be') copulas) have their inverted variants, then of the two instances classified as predicational, only the ones with a być-copula and Instrumental case on one of the DPs have inverted counterparts, as illustrated below:

(18) *Harcerz to Janek.

scout.NOM TO John.NOM

(19) Styczeń to najzimniejszy miesiąc.

January.NOM TO coldest.NOM month.NOM

'January is the coldest month.'

(20) Harcerzem jest Janek.

scout.INST be.PRES.3SG John.NOM

'John is a scout.'

(21) Styczeń jest najzimniejszym miesiącem.

January.NOM be.PRES.3SG coldest.INST month.INST

'January is the coldest month.'

3 The distinction was originally defined for French in which predicate nouns denoting some titles and functions following a copula may or may not be preceded by an indefinite article, which affects the meaning. The version with an article denotes permanent properties, the one without one - temporary characteristics. Roy (2006) argues that the distinction is present in other languages through case alternations. For example, in Russian which, like Polish, features a Nominative-Instrumental alternation on predicate nouns, the version with a Nominative case corresponds to the occurrence of an article in French, and to permanent characteristics, while the version with an Instrumental case to the option of a bare nominal and to transient properties. 
A conspicuous side-effect of the inversion in the cases when it is allowed is a change of the status of the clauses in the predicative-specificational dichotomy. The inverted example (20) appears to have now the semantic properties of a specificational copular clause, while (21) should be characterized as predicational. ${ }^{4}$ In accordance with a persuasive line of argumentation present in the literature, specificational copular clauses are in fact "inverted" predicational clauses (e.g. Williams 1983, Heggie 1988, Moro 1997, 2000, Mikkelsen 2005a, den Dikken 2006). In what follows, we will not be concerned with the semantic effect of inversion but only with its syntactic motivation. Thus, we will look at the syntactic properties of the two types of to-copular clauses, defined semantically as predicational and specificational, and try to establish on strictly derivational grounds why only the latter may have an "inverted" variant.

\section{Earlier analyses}

As noted, the analysis will now focus on the constructions with a non-verbal copula to, leaving the cases with a be copula aside. Below is a brief survey of the treatment of the particle to and copular-to sentences in three earlier accounts. A primary concern will be the structural and derivational properties advanced therein.

\subsection{Rutkowski (2006)}

In Rutkowski's (2006) account the copular to in Polish is argued to be diachronically related to a demonstrative pronoun needed for the resumption of a topic, while its contemporary status is defined as this of an identificational demonstrative. The term is novel, and Rutkowski uses it to refer to a generalized, nonanaphoric, identifying function of to which emerges in Polish also in sentences like (22) below, and is similar to the function of das in a German example (23): ${ }^{5}$
(22) To (jest)
mój
najlepszy
przyjaciel.
TO (be.PRES.3SG)
my.NOM
best.NOM friend.NOM
'This is my best friend.'
Rutkowski (2006: 163)

\footnotetext{
$4 \quad$ I thank both anonymous reviewers of this paper for bringing the importance of this issue to my attention. For a comprehensive discussion on the typology and syntactic and semantic characterization of different types of copular sentences in Polish, see Bondaruk (2013).

5 A different way to characterize to as an identificational demonstrative, which Rutkowski (2006) does not suggest, is to think of it as a kind of expletive subject (like English it), which in Polish is rendered by a homophonous to.
} 
(23) Das ist meine Schwester. this.NEUT is my sister.FEM 'This is my sister.'

Following Linde-Usiekniewicz (2007), he takes the structures with to alone and those with to być (as in (24) and (25) below, respectively) to be two variants of the same syntactic pattern, whereby the former is derived from the latter by the deletion of the verb być ('be'), which is possible only in the present tense: ${ }^{6}$

(24) Janek to harcerz. $(=1)$

(25) Janek to jest harcerz.

Janek.NOM TO be.PRES.3SG scout.NOM

'Janek is a scout.'

If so, the crucial characteristics of copular-to sentences is its "NP2-headeness", manifested by (gender and number) agreement with the second NP, as in (26): ${ }^{7}$
Dinozaury
to jest
gatunek
gadów.
Dinosaurs.NOM.PL TO be.PRES.3SG species.NOM.SG reptiles.GEN.PL ${ }^{8}$
'Dinosaurs are a species of reptiles.'
Rutkowski (2006:157)

The structure of a copular-to clause he proposes is (27):

The form jest ('is') is a present tense, singular, third person form of być ('be').

As rightly noted by the anonymous reviewer of this paper, the notion of "NP2-headeness" used by Rutkowski (2006), who follows Linde-Usiekniewicz's (2007), "is not very helpful, as this is not the usual meaning of "head" in generative syntax".

8 The original glosses used by the authors have been adjusted to the convention used in this paper. 
(27)

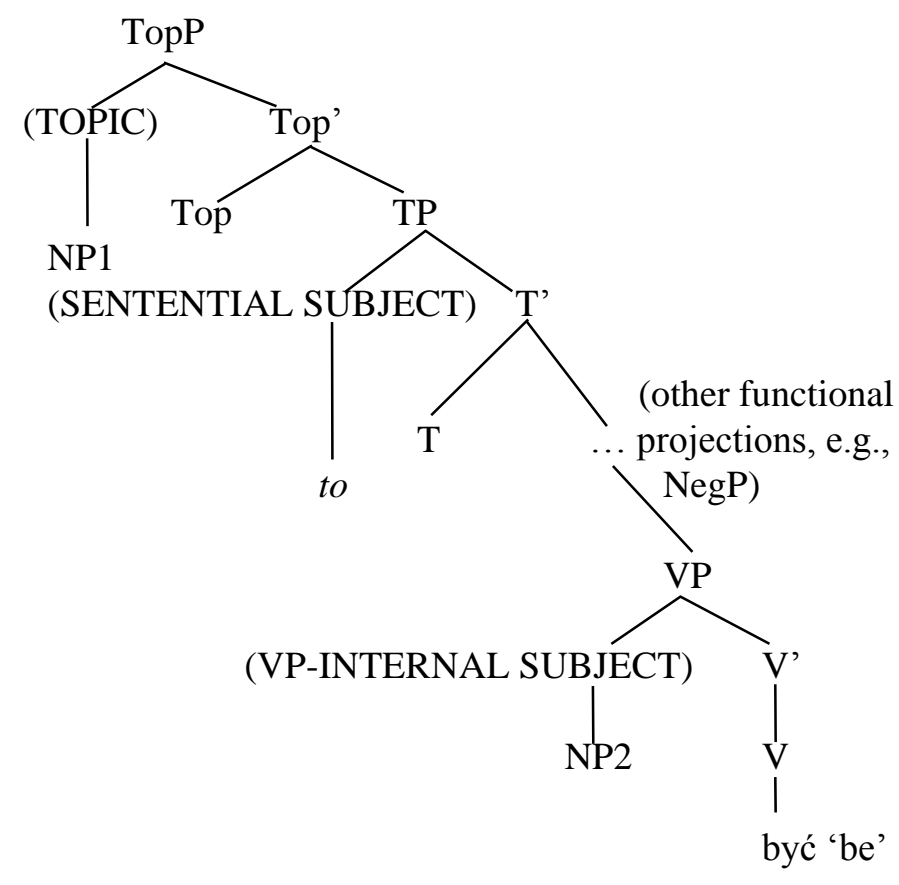

Rutkowski (2006: 165)

As can be seen in (27), the demonstrative pronoun to occupies a subject (Spec. $\mathrm{TP})$ position, while NP1 occupies a topic (Spec.TopP) position.

One can raise a few questions about this proposal. First, the position of Spec. TopP is referred to as left-dislocated, which suggests that NP1(topic) is in its in situ (base-derived) position. As standard in left-dislocation, it is the resumptive pronoun that takes the responsibility for theta role identification of the leftdislocated phrase (topic) in the structure, as schematically shown in (28): ${ }^{9}$

(28) Co do dinozaurów, to to jest gatunek gadów.

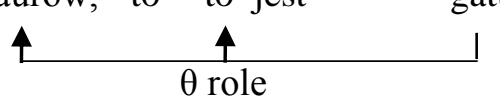

what to dinosaurs.GEN TO it be.PRES.3SG species.NOM reptiles.GEN

'As for dinosaurs, it is a species of reptiles.'

9 Rutkowski (2006) claims that Polish does not allow resumptive pronouns, at all. Examples like (28) appear to challenge this assumption. 
The problem with structure in (27) is however, that it postulates base-derivation of the external argument in Spec.TopP with no possible theta identification through the resumptive pronoun to, which itself is base-derived outside of the VP (Predicate Phrase).

Second, sentence (28) is troublesome for Rutkowski's account also because it features the presence of to next to the homophonous true resumptive pronoun to ('it'), The appearance of two resumptive pronouns in a structure is rather dubious and suggests the different status of the first $t o$.

The third problem, noticed by Bondaruk (2013), is that, as evident from cases like (29) below, a DP (NP1) preceding to may bind an anaphor within the VP:

(29) Janek j $_{\mathrm{i}}$ to swój $\mathrm{j}_{\mathrm{i}}$ najlepszy obrońca.

Janek.NOM TO his best.NOM defender.NOM

'Janek $\mathrm{k}_{\mathrm{i}}$ (himself) is his $\mathrm{s}_{\mathrm{i}}$ best defender'

Given (29), either Janek occupies the subject (Spec. TP) (as assumed by Bondaruk (2013)) from where it binds the anaphor or it had to be raised from some lower position, so that its lower copy could bind the anaphor. In either case, it could not have been base-derived in a left-dislocated position (presumably an A'-position).

What sounds convincing in this account is reference to the interpretation of NP1 in (27) as topic. But, then, it is surprising why there is no mention at all of other uses of to in non-copular clauses, like (4) above, repeated as (30), where to seems to have the same topic-indicating function:
Janek
to pomógt
starszej
pani.
Janek.NOM TO help.PST.3SG.M older.DAT lady.DAT
'As for Janek, he helped an elderly lady.'

\subsection{Citko (2008)}

Unlike Rutkowski (2006) and Linde-Usiekniewicz (2007), Citko (2008) does not assume that the form to is optionally derived from to byc by the deletion of być. Instead, she divides Polish copular clauses into three types: verbal, nonverbal and dual, whereby the first features a form of $b e$, the second a non-verbal pronominal to, and the third - the two elements combined together into to+be. Despite such a tripartite division she still maintains a uniform structural analysis for the latter two types, given in (31) below: 


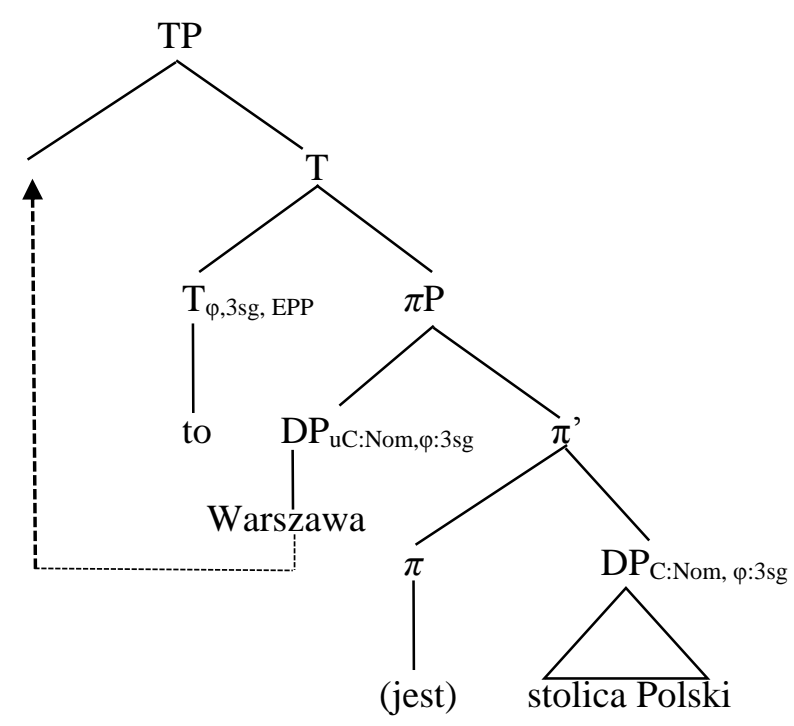

TO Warsaw be.PRES.3SG capital.NOM Poland.GEN 'Warsaw is the capital of Poland.'

cf. Citko (2008: 292)

The ultimate order of constituents in (31) results from the movement of the DP in Spec. $\pi \mathrm{P}$ to Spec. TP due to the presence of the EPP feature on $\mathrm{T}$, as schematized in the diagram.

For Citko (2008), Polish copular clauses contain a Predicative Phrase (called $\pi \mathrm{P}$ in (31)) which are instances of small clauses headed by a predicator head, which may be defective or non-defective. A complete (non-defective) version of $\pi$ is instantiated by the sole presence of the copula być. It is equipped with a set of uninterpretable $\varphi$-features and an optional EPP feature. It values the Case feature on its DP complement as Instrumental. The defective option of $\pi$ has two variants: a null variant, or a form of być ('be'). In either case, the appearance of the defective $\pi$ is accompanied by the presence of the pronominal copula to under T. The defective $\pi$ lacks any $\varphi$ features and cannot value Case. The status of to is two-fold, it is a T head, but also a kind of coordinator, so that its presence in a structure enforces two types of symmetries between the DPs on both sides of to: Subject-Predicate category congruence and Subject-Predicate Nominative case-matching, as illustrated below: ${ }^{10}$

10 Both these symmetries are derived from the defectiveness of $\pi$. As discussed by Citko (2008), the defectiveness of $\pi$ in to być and to-copular clauses is like the defectiveness of a coordination head (\&) in [\&P XP [\&, \& XP]] which also requires congruence of category and 
(32) Tomek to mój kolega/*moim kolegą Tomek.NOM TO my.NOM friend.NOM/*my.INST friend.INST 'Tomek is my colleague.'

(33) [DPTomek] to [DPchłopiec]/*[AP wesoły], *[PP W szkole] Tomek.NOM TO boy.NOM/*jolly.NOM/*at school 'Tomek is a boy/jolly/at school

The approach has many advantages, but one can raise a few doubts, as well. First, as noted by Balazs (2012), the non-verbal copula to alone has a limited tense interpretation. It can only denote a present time reference, as shown in (34) and (35):

(34)

$\begin{array}{lllll}\text { *Wczoraj/*jutro } & \text { Maria } & \text { to } & \text { smutna } & \text { dziewczyna. } \\ \text { yesterday/tomorrow } & \text { Mary.NOM } & \text { TO } & \text { sad.NOM } & \text { girl.NOM }\end{array}$

Dzisiaj Maria to wesoła dziewczyna. today Mary.NOM TO jolly.NOM girl.NOM 'Mary is a jolly girl today'. cf. Balazs (2012: 71)

The restriction disappears, however, for a dual to być form:

(36) Wczoraj Maria to była smutna dziewczyna. yesterday Mary.NOM TO be.PST.3SG.F sad.NOM girl.NOM 'Yesterday, Mary was a sad girl'.

(37) Jutro Maria to będzie wesoła dziewczyna. tomorrow Mary.NOM TO be.FUT.3SG jolly.NOM girl.NOM 'Tomorrow, Mary will be a jolly girl'.

These facts are troublesome for Citko's account in two respects; (i) if the overt być in examples (36) and (37) is a defective instance of a predicator head $(\pi)$, which does not differ from its null variant used in (34) and (35) (it introduces no special features to structure (31)), then it is unclear why its absence should result in the ungrammaticality of (34), (ii) the presence of to under the T head suggests it is a tense marker, but as such, it could only mark the present tense, given the facts in (34)-(35), but then the appearance of the past or future tense on być $(\pi)$ in (36) and (37) remains unexplained. In other words, Citko's ac-

Case on the two coordinated XPs. This is related to their deficiency in c-selection properties and the lack of case-valuation property (cf. Citko 2008: 288). 
count does not explain the difference in the distribution of the overt and the null variant of the defective $\pi$ observed in (34)-(37) above.

Next, as discussed by Bondaruk (2013: 232), Citko's approach does not explain why, despite the necessary congruence in category membership and case, the two DPs on the sides of to may not agree in $\varphi$-features, as illustrated in (38) and (39) below:

(38) [Ci czterej piłkarze] to [najlepsza obrona w lidze]. these four players.NOM.PL TO best defense.NOM.SG in league 'These four players are the best defence in the league.'

(39) [Dzieci] to [przyszłość narodu] Children.NOM.PL TO future.NOM.SG nation.GEN.SG

'Children are the future of the nation.'

(cf. Citko 2008: 266)

Citko (2008) argues that the defective $\pi$ head is devoid of any $\varphi$-features, and the agreement between the two DPs is ensured by T equipped with a full set of $\varphi$-features, which enters into Multiple Agree with both DPs. Under such a view, the non-congruence in number observed in (38) and (39) is not explained, though.

A further problem for this analysis is that there is a clear difference in grammaticality between cases involving a sole to and the to+byc form when the two DPs disagreeing in number get inverted, as shown by the comparison of (38) above with (40) below, and of (41) with (42):

(40) [Najlepsza obrona w lidze] to [ci czterej piłkarze]

Best defense.NOM.SG in league TO these four players.NOM.PL 'The best defence in the league are these four players.'

(41) [Ci czterej piłkarze] to jest/*są [najlepsza obrona w lidze] these four players.NOM.PL TO be.PRES.3SG/*be.PRES.3PL best defence.NOM.SG in league

(42) [Najlepsza obrona w lidze] to $\mathrm{sa} /{ }^{*}$ jest [ci czterej piłkarze] best defence.NOM.SG in league TO be.PRES.3PL/*be.PRES.3SG these four players.NOM.PL

There is no restriction on such an inversion in cases involving just to - the plural and the singular DPs may be freely swapped, while in cases involving the 
to + byc swapping is only possible on condition that the form of the copula is adjusted for agreement in number with the second DP. ${ }^{11}$ The situation in (40)(42) shows that either: (i) there is a rule that it must always be the second DP which determines the concord with the verb, or alternatively, (ii) that the presence of to+byc blocks the inversion of the two DPs. The second alternative would hold if the presence of być, immediately represented by some inflected form, i.e. jest ('is', singular) or sa ('are', plural), established an early Agree relation between $\pi$ and the second DP, which could not be modified later. This would effectively block inversion, under a "crash-proof" format of derivations (as of Frampton \& Gutmann 2002). Some structural details of an analysis based on this general idea are briefly presented in section 5 . Whatever the reason for the constraint in (41-42) may be, the assumption that być or its null variant are two options of the same defective predicate head $\pi$ is questionable in view of such facts. It is simply unclear why the optional presence of $b e$ in $\pi$, which is argued to be devoid of any $\varphi$-features, should have such an effect on the agreement facts.

\subsection{Bondaruk (2013)}

Bondaruk (2013), like Rutkowski (2006), assumes that the copular structures with the form to are derived from the structures with to byc by the regular dropping of byc in the present tense. This implies that the two are phonological variants of the same syntactic type. Before proceeding, one may consider the arguments for such a conflation of both variants. The author generally states that the two "do show analogous syntactic properties", which should however be confronted with quite a few differences between the two she lists out. First she notes that to-clauses sound usually more natural than to być-clauses. Thus, for example, in cases involving two prepositional phrases or two adjectives, like (43) and (44) respectively, to is quite natural but to być sounds marginal, at best: ${ }^{12}$

11 The requirement of agreement with the second DP extends to [gender], as discussed by Rutkowski (2006). One of his examples is (i) below:

$\begin{array}{llll}\text { Wanda } & \text { to było/*była } & \text { stare } & \text { babsko. } \\ \text { Wanda.FEM TO be.PST.NEUT/*FEM old.NEUT } & \text { bag.NEUT } \\ & \text { 'Wanda was an old bag, }\end{array}$

12 For example, (43) might be expanded into a conditional Jeśli na dworze to na dworze ('If in the open then in the open') but not into: *Jeśli na dworze to jest na dworze. The anonymous reviewer of the paper doubts whether the occurrence of to in such conditionals can be regarded as a copula at all, and suggests it is rather a correlative of jeśli ('if') entering a pair with $t o$, just like English if in the pair if ...then. However, it seems that to can be said to have the function of a correlative of the conditional jeśli ('if') even if the latter is not phonetically spelt-out. Thus,(43) and (44) can be understood to express condition, e.g. (44) may 


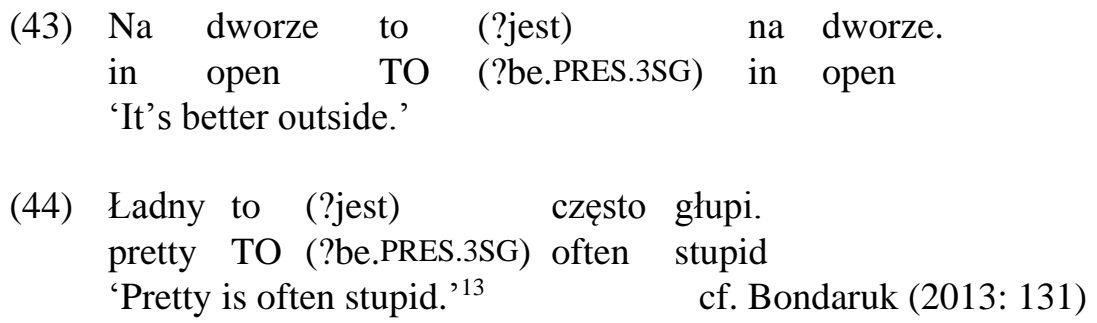

If to and to być forms differ only in phonology, then it is not clear why the contrast observed in (43)-(44) should arise - both types are phonologically neutral. ${ }^{14}$ It seems the type of clumsiness observed in $P P / A P$ to byc $P P / A P$ sequences is more syntactic in nature, and could be related to a difference in the derivation of to- and to być-copular clauses, as proposed in the alternative account in section 4.3.

Another point which may be raised against the proposed conflation of to and to byc forms under one label is the nature of 'być dropping'. If it is the matter of $\mathrm{PF}$, then PF must preserve syntactic information to ensure that the tense is present (not past or future) and deletion is possible, which itself seems a rather costly solution. If deletion occurs in narrow syntax, then we have a new kind of operation: deletion of a non-copy, being another costly solution. ${ }^{15}$

\subsubsection{To as an emphatic marker}

With respect to the particle to itself Bondaruk (2013) makes a distinction between to used in to być copular clauses, discussed so far, and the to used in clauses like (45) below. The major difference between the two types is that the second DP in examples like (45) is in Instrumental, not Nominative case. The author classifies such cases as ungrammatical, unless to is "treated as a marker of emphasis, not a copula"(Bondaruk 2013: 130).

mean Jeśli ładny to często głupi ('If pretty then often stupid'). I think, however, that the functioning of to as a correlative of jeśli should not preclude its status as a copula in such constructions.

13 The other anonymous reviewer asks if the grammatical options in (43) and (44) are not idiomatic expressions, which would weaken the argument. This does not appear to be the case given the general productivity of $A$ to $A$ or $P P$ to $P P$ forms in Polish and the lack of lexical restrictions on their formation.

14 The $P P / A P$ to byc $P P / A P$ sequences are described as marginal at best, but, arguably, they may be considered ungrammatical.

15 The reviewer suggests that instead of "być dropping" it could be assumed that "the present tense of być has two realizations, one of which is null". This would be close to Citko's (2008) two variants of the defective $\pi$ and a viable alternative to Bondaruk's (2013) proposal, but a problem for this solution would be, again, how to account for the contrasts in (43) and (44) i.e. why a null variety of być is OK, while the overt one is not, if the nature of the contrast is not phonological. 
(45) Janek to jest geniuszem

Janek.NOM TO be.PRES.3SG genius.INST

'Janek is a genius.' cf. Bondaruk (2013: 130)

She further notes that the use of to as an emphatic marker occurs in Polish also in other types of sentences, and her example is (46):

(46) Marek to do mnie zadzwonił.

Marek.EMPH TO to me call.PST.3SG.M

'It is Mark that has called me.' (Bondaruk 2013: 130)

The classification of to in examples like (45) and (46) as an emphatic marker raises some doubts. First, it is not explained what sense of emphasis is evoked in this case. Following the classic distinction proposed in Armstrong \& Ward (1926), it is useful to distinguish two types of emphasis: emphasis for contrast and emphasis for intensity. As defined by Kohler (2006: 4), emphasis for contrast is "special prominence which a speaker gives to certain words for rational highlighting and expression of contrast to what has been said", while emphasis for intensity is "special prominence to amplify the meaning of words and to express a particularly great degree of what they imply". Kohler (2006) proposes to rename the dichotomy as focus vs. intensity. It is unclear if Bondaruk (2013) takes to in (45) and (46) to be a marker of focus or intensity, or both.

Second, there is no clear sense in which the use of to in (46) marks either focus or intensity. The translation of (46) she provides does not explicate the issue; (46) is translated as an English cleft sentence in which the subject (Mark) is in focus, which would suggest that emphasis is understood here as focus. But, the problem is that the Polish sentence in (46) does not have the meaning corresponding to the English it-cleft which is given as its translation. Rather, a Polish counterpart of the English translation in (46) should be (47) below, an instance of a so-called to-cleft introduced earlier, in which the particle to precedes rather than follows the subject: ${ }^{16}$

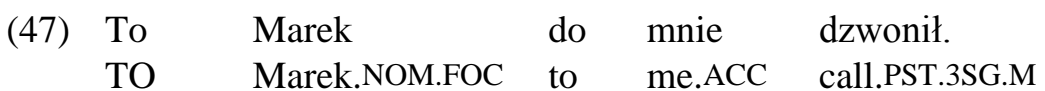

'It is Mark that has called me.'

16 The meaning of (46) is in turn much closer to English (i), with Marek understood as topic: (i) As for Mark, he has called me. 
The sentences in (45) and (46) do not appear to mark intensity, either, if this is understood in the sense of English emphatic constructions, like (48) or (49) below, in which the predicates are made emphatic:

(48) John IS a genius.

(49) Mark DID call me.

Polish translations of (48) and (49) should rather be like (50) and (51), not (45) and (46):
(50) Jan
JEST geniuszem.
Jan.NOM be.PRES.3SG.EMPH genius.INSTR
'Jan IS a genius.'
(51) Marek naprawdę do mnie zadzwonił
Marek.NOM really to me call.PAST.3SG.M

'Marek really called me.'

Next, if to could function as an emphatic marker, it would be difficult to explain why it cannot co-occur with the copular to in one sentence. For example, (52) should be OK with one to marking predication, as a non-verbal copula, and the other marking emphasis. This, however, is not the case: ${ }^{17}$

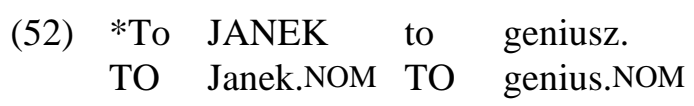

Likewise, treating to as a pure marker of emphasis appears dubious in view of some left-dislocation facts in Polish. As already noted, the productive type of left-dislocation in Polish with the use of a resumptive pronoun are sentences like (53), below:

17 The anonymous reviewer questions the validity of (52) as counterevidence to treating to as an emphatic marker because in (52) the alleged emphatic to precedes Janek instead of following it, unlike in (45). She/he further notes that if the emphatic to followed Janek and immediately preceded the copular to, as in *Janek to to geniusz we would have a case of the unwanted repetition of homophonous elements, which could be the reason of ungrammaticality. However, limiting the use of the emphatic to to just one syntactic position, i.e. to the position preceding a form of the verb być ('be') in examples like (45), is unconvincing. If to could really be an emphatic marker it should be proven that it functions in this mode more productively. 
(53) Co do Janka, to on jest harcerzem/harcerz. what to Janek.GEN TO he be.PRES.3SG scout.INST/scout.NOM 'As for Janek, he is a scout'.

If to was an emphatic marker, there would be no reason why it should not be used in constructions like (54) or (55), below:

(54) *Co do Janka, to on to harcerz. what to Janek $\mathrm{GEN}_{\mathrm{GE}}$ to he to scout $\mathrm{NOM}$

(55) *Co do Janka, to on to jest harcerzem/harcerz what to Janek.GEN to he to is scout.INST/scout.NOM

As already noted, Bondaruk (2013) explicitly assigns the status of an emphatic marker to the occurrence of to in so called być-copular clauses in Polish in which the second DP carries an Instrumental case, exemplified by (45) above. She suggests further that the same function of to may emerge in other structures, providing example (46). Given this prediction, it appears justified to confront the alleged emphatic status of to with two further prominent uses of to in Polish, identified earlier as to-clefts and topic-to sentences, exemplified by (3) and (4) above, repeated here for convenience.

(3) To Janek

pomógł

starszej pani.

TO Janek.NOM.FOC help.PST.3SG.M

older.DAT lady.DAT

'It was Janek who helped an elderly lady.'

(4) Janek

to pomóg1

starszej pani.

Janek.NOM.TOP TO help.PST.3SG.M

older.DAT lady.DAT

'As for Janek, he helped an elderly lady.'

Examples (3) and (4) indicate two positions in which the particle to may occur; one is a front position immediately before a focused constituent, the other is the "second" position, right after the first constituent identified as topic. A larger set of examples below show that other positions are not available to it: ${ }^{18}$

18 However, an object or an adjunct can appear immediately before or right after to if they undergo Internal Merge, as in (i) below:
(i)
$\begin{array}{ll}\text { To } & \text { starszej pani } \\ \text { TO } & \text { older lady.DAT.FOC }\end{array}$
Janek
pomógł.

'It was the elderly lady that Janek helped.' 


\begin{tabular}{|c|c|c|c|c|}
\hline $\begin{array}{l}\text { (56) } \text { *Janek } \\
\text { Janek.NOM }\end{array}$ & $\begin{array}{l}\text { pomógł } \\
\text { help.PST.3SG.M }\end{array}$ & $\begin{array}{ll}\text { to } & \text { starszej } \\
\text { TO } & \text { older.DAT }\end{array}$ & $\begin{array}{l}\text { pani } \\
\text { lady. }\end{array}$ & \\
\hline 7) *Janek pom & ógł starszej pani & & & \\
\hline $\begin{array}{l}\text { *Janek } \\
\text { Janek.NOM }\end{array}$ & $\begin{array}{l}\text { pomógł } \\
\text { help.PST.3SG.M }\end{array}$ & $\begin{array}{ll}\text { starszej } & \text { pani } \\
\text { older.DAT } & \text { lady.DAT }\end{array}$ & $\begin{array}{l}\text { to } \\
\mathrm{TO}\end{array}$ & $\begin{array}{l}\text { [PPW autobusie] } \\
\text { on bus }\end{array}$ \\
\hline $\begin{array}{l}\text { *) Janek } \\
\text { Janek.NOM }\end{array}$ & $\begin{array}{l}\text { pomógł } \\
\text { help.PST.3SG.M }\end{array}$ & $\begin{array}{ll}\text { starszej } & \text { pani } \\
\text { older.DAT } & \text { lady.DAT }\end{array}$ & $\begin{array}{l}\text { to } \\
\text { TO }\end{array}$ & $\begin{array}{l}\text { [NP/AdvWczoraj] } \\
\text { yesterday }\end{array}$ \\
\hline
\end{tabular}

It is worth noting that the restrictions on the positioning of to are in sharp contrast with the syntax of English focus operators, such as only or even, which appear to be much more flexible in this respect:

(60) Only/even TOM met John in the pub.

(61) Tom only/even MET John in the pub.

(62) Tom only/even met JOHN in the pub.

(63) Tom met only/even TOM in the pub.

(64) Tom met John only/even in the PUB.

(65) Tom met John in the pub only YESTERDAY.

The observed difference suggests that to is unlike English focus operators only or even in that the latter can be merged separately with a variety of sentence constituents, while the former cannot. ${ }^{19}$ The reviewer remarks that one should not expect every focus-sensitive operator to have the same syntax as English only, which is right. But, the question remains why the emphasizing effect of to on a ccommanded constituent can only be exerted from the front or "second" position in a structure. Another question is why it cannot merge separately with particular sentence constituents at subsequent stages of the derivation. The answer we tentatively suggest is that the to occurring in to-clefts and topic-to sentences is not different from the to appearing in copular-to clauses. As such, as will be elaborated on shortly, it has the status of a Pred ${ }^{0}$ head which is first merged in the structure only at a particular point of derivation, hence its limited structural position. ${ }^{20}$

19 The anonymous reviewer notes that only "cannot be attached just anywhere: e.g. I can focus the object by putting "only" before the verb, but not in the sentence initial position: I only saw JOHN; *Only I saw JOHN." But, this is a restriction on the scope of only and its interaction with focal stress, not on its position in a sentence. The questions of the scope of focus-sensitive operators, their interaction with focal stress and the semantics of the structures in which they appear are of major importance but are beyond the scope of this paper.

As argued for in Tajsner (forthcoming) the front position of to in to-clefts is derived by a 


\subsubsection{Structure of non-verbal copular sentences}

Let us now return to Bondaruk's (2013) analysis of non-verbal copular sentences. She advocates the following structural proposal:

(66)

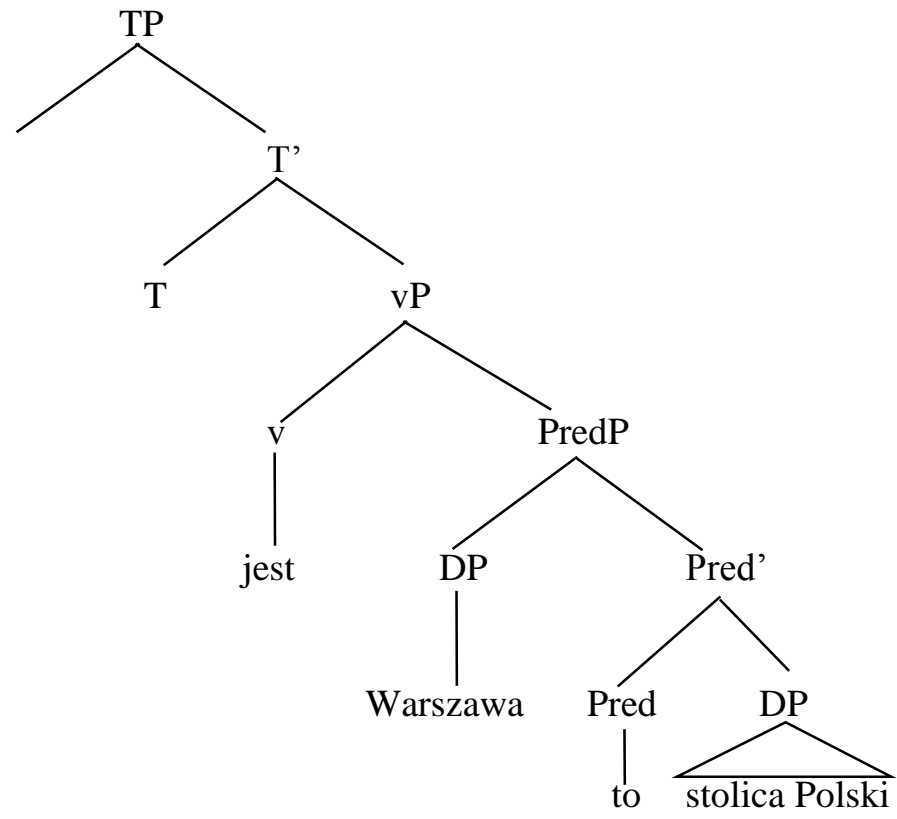

Bondaruk (2013: 233)

The crucial points of the analysis are: (i) the treatment of to as a predicative head, (ii) placing the verbal copular jest ('is') under v, (iii) PF movement (pronominal clitic climbing) of to to a position before jest, (iv) movement of the higher DP (Warszawa) to Spec. TP, (v) treating jest as a raising verb.

A few remarks may be in order with respect to the proposal in (66). First, it seems necessary to add to the analysis that if the vP in (66) is a phase then the higher DP cannot proceed directly from Spec. Pred.P to Spec. TP without stopping at the edge of $\mathrm{vP}$, which would require the presence of another EPP feature in v. Next, as noted, there are left-dislocation structures in which a resumptive pronoun (e.g. on ('he')) appears between to and jest ('is'), as in (67): 
(67) Co do Janka, to on jest harcerz.

what to Janek.NOM TO he be.PRES.3SG scout.NOM

'As for Janek, he is a scout.'

It would be difficult to find a place for the resumptive pronoun in structure (66). ${ }^{21}$ If to is 'clitic-climbed' at PF to a pre-verbal position, then the pronoun in (67) does not reach as high as the Spec. of TP, and the EPP feature on T cannot be checked. Maybe, the position of Spec. $\mathrm{vP}$, could be available for the pronoun, but presumably only as an escape hatch and not an ultimate landing site, given there is still an EPP feature on T to check. Next, the placement of sentential adverbs like chyba ('perhaps'), zapewne ('certainly') between to and jest, which Bondaruk (2013), following Witkoś (1998), attributes to a possible preverbal, but not the verb-adjacent position of pronominal clitics, becomes problematic for the cases in which there is no być, only to, like (68) below:

$\begin{array}{lll}\text { (68) Janek to zapewne } & \text { harcerz. } \\ \text { Janek.NOM TO certainly } & \text { scout.NOM } \\ \text { 'Janek certainly is a scout.' } & \end{array}$

If there is no verb in (68), then there cannot be to-climbing to a pre-verbal position. But, if to stays in situ then the adverb could only be base-adjoined to the lower DP - a highly problematic solution. Finally, sentences like (69), in which a wh-phrase is raised from the complement of the noun would need to have a place to accommodate a wh-phrase between to and jest ('is'). Ideally, for checking the wh-feature, it should be a Spec. ForceP (or Spec.FinP) position. The structure in (66) has no such position to offer. ${ }^{22}$

21 The anonymous reviewer objects to this point noting that the to appearing in (67) should not be regarded as a copula, by analogy to the status of to in non-copular left-dislocation examples like (i) below:

(i) Co do Janka, to on wyjechat do Londynu ('As for Janek, he left for London').

However, the proposal extended in section 4 aims at the unitary treatment of to in typical copular-to clauses, less typical cases like (67), and non-copular examples, like (i). The key parameter for such a unitary account is the higher structural position of to, regarded as a Pred head, allowing for the placement of additional material between to and the form of $b y c$ ('be'). Whether the occurrence of to in (67) qualifies as a copula in a traditional sense may, indeed, be unclear.

22 There is a possibility, pointed out by the reviewer, that the wh-phrase moves to Spec. vP if v has an edge feature. But Spec. vP would then have to be not only an escape-hatch, but also a (possibly alternative) criterial position for wh-movement (in the sense of Rizzi 2006). This would be a rather unorthodox view of Polish wh-movement. The reviewer mentions examples like Marek co wczoraj kupit ('Marek what yesterday bought?') for an illustration of such a short wh-movement in Polish. However, such an example suggests a topic interpretation (it seems a comma is needed in the written form of such examples separating the sub- 


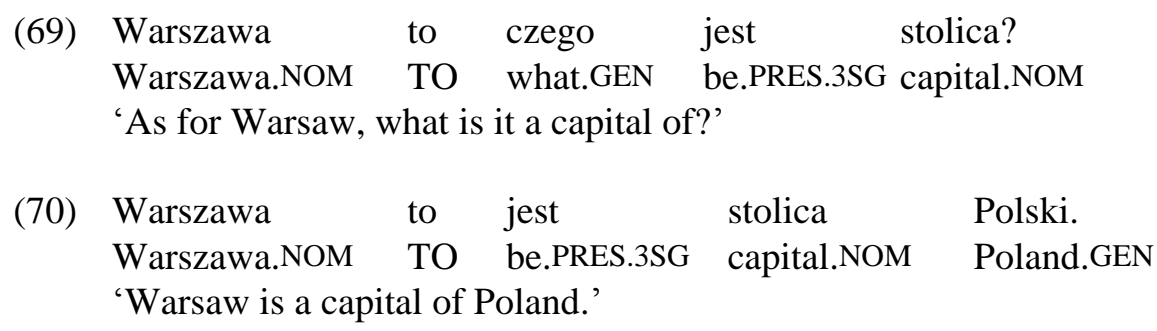

Thus, it may be concluded that there are problems with the three assumptions made in Bondaruk's (2013) approach to non-verbal copular sentences, namely: (i) that to and to być are two variants of the same copula, related to each other by phonological być-dropping, (ii) that when used in so-called być-copular clauses to functions only as an emphatic marker, and (iii) that the structures of to and to być copular clauses are jointly represented by (66).

\section{A more unitary proposal}

An alternative to the three analyses presented above could be a more derivational, unified approach to the two types of non-verbal copular sentences in Polish; predicational and specificational, exemplified by the earlier examples (5) and (6), repeated below as (71) and (72):
(71) Janek to harcerz. (predicational) Janek.NOM TO scout.NOM 'Janek is a scout.' $\begin{array}{llll}\text { (72) Najzimniejszy } & \text { miesiąc to } & \text { styczeń. (specificational) } \\ \text { coldest.NOM } & \text { month.NOM TO January.NOM }\end{array}$

\subsection{Small clauses as predication}

A starting premise can be a generally accepted view that copular sentences are derived from small clauses (e.g. Stowell 1981, Koopman \& Sportiche 1991, Chomsky 1995, Hale \& Keyser 2002, Progovac 2010). In particular, we will follow Chomsky's (2013) view that a small clause is an asymmetrical, labelled structure, whose formation has to be preceded by an earlier, label-less and symmetrical stage. A symmetrical stage for a copular-to clause in (71) is illustrated in (73):

ject DP and the wh-word (i.e. Marek, co wczoraj kupit? )). It is therefore possible that the subject (Marek) has been merged in a higher (topic) position. 


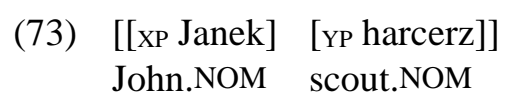

The array in (73) is an outcome of pure Concatenate (as of Hornstein 2009). Chomsky (2013: 43) argues that the Labeling Algorithm (LA) will always promote a head for a label in the array $\{\mathrm{H}, \mathrm{XP}\}$. The problem with (73) is however, that the array in (73) is not $\{\mathrm{H}, \mathrm{XP}\}$, but rather $\{\mathrm{XP}, \mathrm{YP}\}$, which appears symmetric, so the question arises in what sense the derivation can pass to the asymmetric stage needed for the formation of a small clause. We will argue that the inherent asymmetry of the array in (73) lies in the difference in the encoded specificity of the two concatenated phrases: XP (Janek) is specific and YP (harcerz) is non-specific. Given the potential indeterminacy of the notion of specificity, section 4.1.1 below is devoted to a brief explanation of how the notion is used in the present context.

Before we turn to this, let us examine the category status of the two concatenated nominal phrases in (73). The options for the array $\{\mathrm{XP}, \mathrm{YP}\}$ are $\{\mathrm{DP}$, DP $\},\{N P, N P\},\{D P, N P\}$ and $\{N P, D P\}$ and the choice among them dwells on the "NP or DP" debate for article-less languages like Polish (e.g. Willim 2000, Pereltsvaig 2007, Bošković 2008, 2012, Bošković \& Gajewski 2011). In what follows, we will assume, after Rappaport (2001), Pereltsvaig (2007), LindeUsiekniewicz \& Rutkowski (2006), Citko (2011), Bondaruk (2013), and others that nominal phrases in Polish are generally DPs, but, as proposed by Rappaport (2001) and Pereltsvaig (2001), we will assume that the whole DP structure need not be projected in predicate nominals. We find support for the latter claim in the observed differences in the extraction possibilities out of predicate nominals. As shown in (74)-(77) below, extraction out of a predicate nominal is possible in copular-być clauses in which the predicate noun is in an Instrumental Case, but not in copular-to clauses in which it is in Nominative:

$\begin{array}{lcc}\text { Janek jest } & \text { prezesem } & \text { klubu } \\ \text { jeździeckiego. } & & \\ \begin{array}{l}\text { Janek.NOM be.PRES.3SG } \\ \text { horse-riding.GEN }\end{array} & \text { chairman.INST.SG.M } & \text { club.GEN } \\ \text { 'Janek is the chairman of the horse-riding club'. } & \end{array}$
Którego klubu
jest
which.GEN club.GEN be.PRES.3SG
Janek
prezesem __?
'Of which club is Janek the chairman?'
(76) Janek to prezes klubu jeździeckiego.
Janek.NOM TO chairman.NOM club.GEN.SG horse-riding.GEN
'Janek is the chairman of the horse-riding club'.




$\begin{array}{lllll}* \text { Którego } & \text { klubu } & \text { Janek } & \text { to } & \text { prezes } \\ \text { which.GEN } & \text { club.GEN } & \text { Janek.NOM } & \text { TO } & \text { chairman.NOM }\end{array}$

Given the well-attested blocking effect of a DP, we interpret the facts above as showing that the second nominal in copular-to clauses is a DP, while the same nominal in copular-byc clauses is an NP. ${ }^{23}$ In conclusion, the array in (73) will be taken to have the following category instantiation:

(78) [[DP Janek] [DP harcerz $]$

John.NOM scout.NOM

\subsubsection{Specificity syntactically encoded}

Specificity is a notion from the interface of syntax and semantics. The semantic sense of specificity adopted here owes to Enç's (1991) tripartite distinction among nominal phrases; (i) definite NPs, which are always specific, (ii) indefinite specific NPs, and (iii) indefinite non-specific NPs. The distinction is based on the relations of NPs to referents in discourse. Thus, an identity relation holds between a definite NP and a discourse referent, and an inclusion or a partitive relation between a referent and an indefinite specific NP. Indefinite non-specific NPs have no referent in the discourse.

A predicate noun, e.g. harcerz ('scout') in (66), is a non-referring expression and falls in the category of non-specific phrases. ${ }^{24}$ However, an appeal to a discourse-related property, such as reference, cannot be a motivation for the turns of a syntactic derivation. Thus, what is needed is an account of the syntactic coding of specificity in the structure of a nominal phrase. A persuasive framework which can be used for this purpose is Campbell's (1996). Dwelling on the DP Hypothesis, Campbell (1996) puts forth a proposal that every DP contains in its internal structure a small clause with a noun as its Predicate, and an empty element $e$ representing its Subject, as given in (79) below:

$$
\left[D P \ldots D \ldots\left[s c \text { e } e_{i} N\right]\right]
$$

For a specific (definite) DP, e.g. the thief, the structure in (79) is instantiated as in (80):

23 The facts observed by Roy (2006), referred to in note 3, about the presence or absence of an article with predicate nominals in French, and the generalization drawn therein with respect to the Instrumental-Nominative alternation cross-linguistically point to the same direction.

24 Under some classifications, a predicate nominal constitutes a separate sub-type of nonspecific NPs. For example, von Heusinger (2002), following Prince (1981) classifies it as a predicative type, distinguishing it from such other types of non-specific NPs as generic, attributive and negative polarity idiom-piece (von Heusinger 2002: 11). 
(80) [DP $\mathrm{O}_{\mathrm{i}}$ the $\left[\operatorname{ArtP} \mathrm{e}_{\mathrm{i}}\left[\mathrm{NP} \mathrm{e}_{\mathrm{i}}\right.\right.$ thief $\left.\left.]\right]\right]$

Thus, in a specific DP the empty $e$ becomes an indexed variable $e_{i}$ bound by a specificity operator $\mathrm{O}_{\mathrm{i}}$ (null or represented by a demonstrative) which is situated in the Spec. DP. Additionally, Campbell (1996) assumes that an English nominal small clause is always ArtP whose Specifier is filled with another copy of the variable $\mathrm{e}_{\mathrm{i}}$. In contrast to this, the structure of a non-specific DP, e.g. a boy, is represented as in (81):

(81) [DP D [ArtP $\mathrm{e}_{\mathrm{i}}\left[\mathrm{Art}^{\prime} \mathrm{a}\left[\mathrm{NP}[\mathrm{e}]_{\mathrm{i}}[\mathrm{N}\right.\right.$, boy $\left.\left.\left.\left.]\right]\right]\right]\right]$ adapted from Campbell (1996: 167)

The crucial difference between the structures (80) and (81) is that the Specifier position of the former, but not of the latter, is filled with a specificity operator. This allows to explain the well-known Specificity Effect, illustrated by the contrast in the pair of examples in (82): ${ }^{25}$

(82) a. *Who did Fred read [the stories about e]?

b. Who did Fred read [stories about e]?

(Campbell 1996: 164)

In (82a) the position of the Specifier of the DP is filled with the specificity operator and hence blocks wh-extraction. No such effect is observed in (82b) in which the Spec. DP position is empty and available as an escape hatch for whextraction.

Campbell's proposal applies to the analysis of English predicate nominals in copular clauses with a view of explaining the difference in the availability of inversion for specific and non-specific predicate nominals, as illustrated below:

(83) John is the culprit./The culprit is John.

(84) John is a student./*A student is John

(Campbell 1996: 169f)

He argues that inversion is possible in (83) because both nominal expressions are maximal expansions (and specific DP), while in (84) the non-specific predicate nominal is just Art', which, being a non-maximal projection, cannot undergo movement (for details see Campbell 1996: 169ff).

25 The Specificity Effect appears to hold also in Polish, as seen in the contrast between (i) and (ii):

(i) $\quad[\mathrm{O} \mathrm{kim}]_{\mathrm{i}} \quad$ czytałeś opowiadania $\mathrm{e}_{\mathrm{i}}$

about who.LOC read.PST.3SG.M stories.ACC

'Who did you read stories about?'

(ii) ??[O kim $]_{\mathrm{i}}$ czytałeś opowiadania Iwaszkiewicza $\mathrm{e}_{\mathrm{i}}$ about who.LOC read.PST.3SG.M stories.ACC Iwaszkiewicz.GEN 
In what follows, we adopt Campbell's (1996) proposal for the structural difference between specific and non-specific DPs, but not his account of the inversion facts in (83)-(84). The reason for this is that the latter analysis presupposes the structure in (85) as a small clause basis of a copular clause (84):

\section{[ArtP John[Art' a student]]}

In derivational terms, structure (85) can only be a result of External Merge (merging John with Art'). We find this proposal incompatible with the view of small clauses we adopt after Moro (2008) or Chomsky (2013) in which the first step in their formation is the concatenation of two maximal nominal projections. ${ }^{26}$

Thus, in the subsequent analysis of Polish copular-to clauses we can make the following assumptions based on Campbell's (1996) theory of Specificity:

(a) There is a structural difference between specific and non-specific DPs. Only the former contain a specificity operator in Spec. DP;

(b) In Polish, an articles language, there is no ArtP projection within the DP;

(c) A detailed representation of the array in (78) is (86):

$$
\left[\left[\mathrm{DP}_{\mathrm{O}} \mathrm{O}_{\mathrm{i}}[\mathrm{D} Q]\left[\mathrm{NP}[\mathrm{e}]_{\mathrm{i}} \text { Janek]] [DP [D Q] [NP pro harcerz]] }\right]^{27}\right.\right.
$$

(d) We adapt Campbell's (1996) representations to a derivational framework by making two natural assumptions: (i) in the formation of a specific DP, the specificity operator is first merged with the noun; (ii) the operator is then internally merged in Spec. DP leaving behind a variable.

\subsection{Breaking the symmetry}

Let us now return to the question of how the array in (78), repeated below as (87), with the detailed representation as in (86), passes to the asymmetric stage of the derivation.

(87) [[DP1 Janek] [DP2 harcerz]]

John.NOM scout.NOM

26 We think that such a selective approach to Campbell's (1996) theory is justified as the two proposals he makes; (i) with respect to the specificity/non-specificity contrast in DPs, and (ii) for the structure of two types of predicate nominals are independent of each other. What is needed, however, is a different account of the contrasts in inversion cases, which is provided further.

27 We interpret the unbound empty category in the subject position of the nominal small clause as pro. 
As established above, of the two DPs in (87), $\mathrm{DP}_{1}$ is specific, and $\mathrm{DP}_{2}$ is non-specific. We assume that in the array (87) it must be the non-specific DP which gives a label to the array (projects) on the following grounds. If the non-specific $\mathrm{DP}_{2}$ projects then it transfers its non-specific status to the labelled array, so that in (88) the projection of $\mathrm{DP}_{2}$ is also a non-specific DP. As such, it does not contain a Specificity Operator, and hence no Specificity Effect is induced which would block the internal Merge of $\mathrm{DP}_{1}$, needed for the expansion of the structure.

\section{(88) [DP2[DP1 Janek] [DP2 harcerz]]}

If, on the other hand, $\mathrm{DP}_{1}$ projected in (87) giving rise to (89), then the internal Merge of $\mathrm{DP}_{2}$ would be blocked by the Specificity Effect due to the presence of the Specificity Operator in the (Specifier of the) projection of $\mathrm{DP}_{1 .}{ }^{28}$

\section{(89) $\left[\mathrm{DP} 1 \mathrm{O}_{\mathrm{i}}\left[\mathrm{DP} 1\left[\mathrm{DP} 1 \mathrm{e}_{\mathrm{i}}\right.\right.\right.$ Janek] [DP2 harcerz $\left.\left.]\right]\right]$}

It can thus be established that the only possible array is (88) with a non-specific DP projecting. Though already labelled, (89) is still too symmetrical for the needs of linearization. As discussed by Moro (2008), a structure like (89) violates LCA, due to the lack of structural anti-symmetry between the two DPs (neither asymmetrically c-commands the other). Following Chomsky (2013), who adopts the ideas of Moro $(2000,2008)$; it will be assumed that a way of breaking the symmetry of (89) is by Internal Merge. ${ }^{29}$ Since a non-specific DP projects, then a specific (referential) DP internally merges, resulting in (90):

\section{[DP2[DP1 Janek][DP2[DP1 Janek] [DP2 harcerz]]]}

The structure in (90) is a small clause, which may be thought of as a structural basis for (functional) Predication, with $\mathrm{DP}_{1}$ a Subject and $\mathrm{DP}_{2}$ a Predicate.

Next, following Moro (2000, 2008), it will be assumed that a point of departure for the formation of a copular sentence is the formation of the array: copu-

28 A different motivation for choosing a label in the array $\{\alpha, \beta\}$ could be Boeckx's (2008) Probe-Label Correspondence Axiom (PLCA): "The label of $\{\alpha, \beta\}$ is the Probe, where the Probe=Lexical Item bearing $u$ F". Boeckx 2008: 92. We do not adopt this solution due to the unclear status of a non-specific nominal as a Probe carrying an un-valued feature.

29 In Moro's $(2000,2008)$ Dynamic Antisymmetry theory, there is no feature-triggered Internal Merge - syntactic movement "is a consequence of an intrinsically non-grammatical restriction: the physical or biological need to linearize the linguistic signal" (Moro 2008: 226). It applies as a Last Resort operation. In Chomsky's (2013) reinterpretation of Moro's framework Internal Merge as a form of spontaneous symmetry breaking for linearization and "Internal Merge for feature-checking" co-exist in one system (cf. Chomsky 2013: 45). 
la-small clause. Thus, the next step in the derivation of (71) is the merger of a non-verbal copula to with the DP in (90), as illustrated in (91) below:

$$
t o+[\mathrm{DP} 2[\mathrm{DP} 1 \mathrm{Janek}][\mathrm{DP} 2[\mathrm{DP} 1 \mathrm{DP} 2 \mathrm{harcerz}]]]
$$

\subsection{To as a head of Specification Predicative Phrase}

Before proceeding, an extended comment is needed on the status of the particle to in non-verbal copular sentences and elsewhere. In agreement with Bondaruk (2013), to will be given the status of a head of PredP, i.e. Pred $^{0}$, but it will additionally be linked with its discourse function. As may be observed in (92) - (94) below, when it occurs, it has a role in specifying the following constituent as new, exhaustive, or contrastive (with specified elements underlined):
A:
A, co zrobił
Janek?
and what do.PST.3SG.M
Janek.NOM
A: 'And what did Janek do?'
B: Janek to pomógł starszej pani.(new)
Janek.NOM TO help.PST.3SG.M older.DAT lady.DAT
B: 'As for Janek, he helped an elderly lady'.

(93) To Janek $\quad$ zrobił. (exhaustive)

TO Janek.NOM.FOC do.PST.3SG.M

'It was Janek who did it'.

(94) Janek to harcerz, nie chuligan! ${ }^{30}$ (contrastive)

Janek.NOM.FOC TO scout.NOM, not hooligan.NOM

'Janek is a scout, not a hooligan.'

New information, exhaustivity and contrast are the three notions associated with the category of focus, and this is where the present account gets inspired by Kiss's (2006, 2010) (but also Wedgwood's 2003) hypothesis that focusing is predication. ${ }^{31}$ The cornerstone of the proposal is the linking of specificational

30 The anonymous reviewer rightly notes that in predicational copular clauses the predicate "does not normally bear any contrastive focus, but just information focus." The view of focus advocated in this framework is, however, that the type of focus is not predetermined syntactically, hence the focal stress in cases like (94) can be interpreted contrastively, subject to contextual requirements.

31 The empirical basis for both Wedgwood's (2003) and Kiss's (2006) accounts is basically the same, namely the facts of the Hungarian "focus position", however the two differ substantially in the execution of the idea. Wedgwood (2003) defines the predicational status of focus within the larger framework of a dynamic, inference-sensitive model of grammar in which a central point is a rejection of the idea that focus can be grammatically coded, which is contra Kiss (2006). 
predication with (exhaustive, contrastive) focusing. Following Huber (2002) she argues that "a specificational predicate implies that its specification of the individuals that make up the set denoted by the subject is exhaustive, that is, other alternatives are excluded". In turn, the subject of predication is "associated with an existential presupposition - an open sentence [...] which is provided by the VP" (Kiss 2006: 12). Thus, for the Hungarian sentence (95) below, a presupposition of some $x$ reading a letter constitutes the Subject of predication and the specific value of $\mathrm{X}-$ Peter is the Predicate itself. In structural terms, instead of postulating a dedicated Spec. FocP phrase as a site of focus, she ascribes this role to the Specifier of the PredP. Thus, a focused phrase in Hungarian occupies a Spec. PredP. position, as illustrated in (95), below:

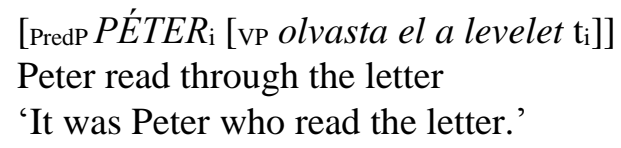

(Kiss 2006: 12)

Thus, specificational predication is a type of relation in which a phrase specified by syntactic means (e.g. by placement in a Spec. PredP position) becomes a syntactic predicate interpreted in discourse as focus. As noted above, for Kiss $(2006,2010)$ specificational predication is linked only with exhaustive or contrastive focus, and not with new information focus. This follows from the empirical basis of the Hungarian focus sentences she adopts. In what follows we propose a different application of the idea, and it should not, therefore, be understood as the extension of Kiss's $(2006,2010)$ proposal to Polish data, but rather as a different account, inspired by the linkage of focus and predication.

A modification proposed in the present context is to understand specification more broadly and associate it with any type of focus, also with new information focus. A specific instantiation for Polish would be designating the particle to as a head of a Predicative Phrase. For clarity, the type of predication in question will be called, after Kiss (2006), Specification Predication, and the corresponding phrasal structure - Specification Predicative Phrase (SPredP).

Furthermore, a way to interpret the potential of the Pred head to to create a Specification Predication will be by ascribing to it the role of a probe with an unvalued, but interpretable feature [+Specification]. The feature would only be valued if matched with an appropriate feature on the goal in its c-commanding domain. We associate the relevant feature on the goal with the focal stress it bears, which is assigned canonically by the Nuclear Stress Rule (as of Halle \& Vergnaud 1987, Cinque 1993) or through some mechanism of stress shift (as discussed e.g. by Zubizarreta 1998, Reinhart 2006), as schemed in (96): 
(96)

$$
\begin{gathered}
{\left[\operatorname{sPred}\left[\operatorname{SPred} t o_{[+ \text {uSpecification }]}\right] \underset{[+ \text { focal stress }]}{[(\ldots) \mathrm{XP}(\ldots)]]}\right.} \\
\text { Probe }
\end{gathered}
$$

Before we proceed, there is one more conceptual point to be made on the relation between Kiss's (2006, 2010) original idea and its extension proposed in this framework. ${ }^{32}$ In Kiss's account, the position of the Specifier of the Specification Predicative Phrase is reserved for an element to be interpreted as focus. Thus, if focusing is a predication then the phrase in Spec. SPredP is a Predicate, while the complement of the predicate head is Subject in the traditional Subject-Predicate partition. In our proposal, Specification Predication is a property of syntactic structure triggered by the merger of a (specification) predicate head Pred $^{0}$ (lexically represented by to in Polish), but the interpretation of the phrases as focus or topic is not strictly determined by the position the phrases occupy in the structure. Rather, a determining factor is their ultimate structural relationship with a predicate head. Thus, it is possible for a phrase positioned in the Specifier of the Specification PredP to be interpreted as focus if it is ultimately c-commanded by the predicate head to. This situation, which crucially requires the instance of reMerge of $\operatorname{Pred}^{0}(t o)$ in a position c-commanding SPredP, occurs in Polish toclefts, exemplified by (3) above, whose analysis is beyond the scope of this paper. ${ }^{33}$ On the other hand, a phrase in Spec. SPred.P will be interpreted as topic if a predicate head stays in situ, and follows the phrase positioned in Spec. SPredP in linear order, which is a situation occurring in Polish copular-to clauses. Correspondingly, an element in Spec. PredP may be considered either a Subject or Predicate in a traditional Subject-Predicate partition, depending on its relation with the predicate head.

\subsection{Derivation continues}

As proposed above, to is regarded as the head of the Specification Predication (SPred), which juxtaposes the constituents to be interpreted at the CI interface as topic and focus. To this end, the predicate head has to check its [+Specification] feature in a probe-goal relation with a focal phrase. This is done in configuration (97):

(97) [[SPred to][DP2 [DP1 Janek][DP2[DP1

32 A need for explicating this point was brought to my attention by the anonymous reviewer.

33 See Tajsner (forthcoming) for the analysis of Polish to-clefts unified with the present account of to-copular clauses. See also note 
Additionally, to is equipped with the EPP feature which triggers the Internal Merge of a non-head of the $\mathrm{DP}_{2}$, i.e. the $\mathrm{DP}_{1}$ Janek in the Spec. PredP, resulting in $(98)::^{34,35}$

(98) [SPredP [DP1 Janek][SPred [SPred $\boldsymbol{t o}$ ][DP2[DP1

Given the lack of any substantial exponent of tense, it will be assumed that there is no $\mathrm{T}$ head in the structure of to-copular clauses. Thus, the presence of Nominative case on the nominal phrases will be accounted for in dissociation from tense, tentatively, as an instance of a default case.

The next to consider is the derivation of a type of a to-copular clause, traditionally referred to as specificational, as in (6) above, repeated below as (99):

(99) Najzimniejszy

miesiąc to styczeń. (specificational)

Coldest moM $_{\text {mon }}$ cop JanuaryNOM

'The coldest month is January.'

The major syntactic difference between the two cases is that the two nominal phrases in the specificational type may be inverted, for which we propose the following account. The early symmetrical stage in the derivation of (99) is given in (100), which is the outcome of pure Concatenate;

(100) [[DP najzimniejszy miesiąc] coldest month

[DP styczeń]]

January

34 The reviewer questions the assumption that in the derivation illustrated by (97) and (98) to agrees (by probing) with a predicate nominal (harcerz) while a different phrase, namely the subject (Janek), merges in the Spec. SPredP. The present analysis dwells on the idea adopted in the probe-goal system (e.g. Chomsky 2004, 2008) of the effective separation of Agree from an instance of Internal Merge for checking an edge feature (EPP). Although the status of EPP is not examined in this paper, we tend to think of it in a broader sense than just a "trigger of XP movement to Spec. TP". Rather, we subscribe to its generalized sense, represented as the OCC feature in Chomsky $(2004,2008)$, as a trigger of all instances of overt Merge, and simultaneously, to its role of an exponent of the requirement of the saturation of predication (see e.g. Bowers 1993, 2003).

35 The other reviewer asks if the derivation goes through if Janek and not harcerz is focused. The answer is "yes" and the result would be an instance of ex situ focus, alternative to toclefts, which is a productive means for exhaustive/contrastive focus in Polish. The resultant sentence would be (i):

(i) JANEK
Janek.NOM.FOC TO harcerz.
'It is Janek who is a scout' 
Unlike in the case of a predicational type, neither of the two DPs in (100) qualifies inherently for the label/head of the array because they both have the same specificity status in the sense elaborated on in 4.1.1. above. But, as noted, the array is too symmetrical for linearization in terms of LCA, hence there is an instance of spontaneous symmetry breaking by selecting freely one of the two DPs for Internal Merge, a mechanism available only for the specificational type but not for the predicational type. ${ }^{36}$ If $\mathrm{DP}_{1}$ is selected, then the configuration (101) is formed in the derivational workspace:

\section{(101) [DP1 najzimniejszy miesiąc] [[DP1}

As discussed in Chomsky (2013), the yet unlabelled array on the right side in the workspace (101) contains one discontinuous element which does not qualify for a label/head. ${ }^{37}$ Hence, it must be $\mathrm{DP}_{2}$ that projects and gives a label to the array of the two DPs on the right side in the workspace in (101). ${ }^{38} \mathrm{Next}, \mathrm{DP}_{1}$ is merged in the Spec.DP 2 resulting in (102):

(102) [DP2[DP1 najzimniejszy miesiąc][DP2[DP1 ajzimniejszy miesiąe] [DP2 styczeń]]]

The difference between the two cases is also that the configuration in (102) is not yet interpreted as an instance of predication. ${ }^{39}$ From this point on, the derivation proceeds like for a predicational type, leading to the formation of (103):

(103) [SPredP[DP1 najzimniejszy miesiąc][SPred[SPred $t o][$ DP2[DP2[DP1 mieseces [DP2[DP1 [DP2 styczeń]]]]]

Just like before, to checks its [+Specification] feature in a probe-goal relationship with the focal phrase styczen' ('January') and an instruction is prepared for

36 This restriction follows from the fact that in predicational copular sentences there is an intermediate stage of label selection (projection) on the basis of the difference in Specificity status. A non-projecting DP is then selected for Internal Merge, hence the choice is no longer free in this case.

37 We follow here the idea, expressed by Chomsky (2013: 44), of a chain formed by Internal Merge as a discontinuous element. Such a chain displays intervention effects, unlike $\mathrm{DP}_{2}$. Chomsky (2013) notes that evoking the concept of a chain (discontinuous element) as a syntactic object is against a convention of treating each copy as a separate element. But, he says "it is quite reasonable to take $\alpha$ to be "in the domain D" if and only if every occurrence of $\alpha$ is a term of D" Chomsky 2013: 44)

38 As noted by Hornstein (2009), an unlabelled array cannot undertake Merge.

39 This presumably follows from the fact that specificational copular-to clauses are "defining" not "characterizing", where "defining" is close to, but not identical with, "equating" observed in equative copular-to clauses like Joseph Conrad to Józef Konrad Korzeniowski ('Joseph Conrad is Józef Konrad Korzeniowski'). 
the CI interface to interpret the DP 1 in the Spec. of PredP as Topic (Subject of Predication) and $\mathrm{DP}_{2}$ as Focus (Predicate) ${ }^{40}$

Finally, although the present account focuses on copular-to clauses, it is worth seeing how it could be extended to to być predicational and specificational copular sentences, exemplified by (104) and (105), respectively:

(104) Janek to jest harcerz.

Janek.NOM TO be.PRES.3SG scout.NOM

'Janek is a scout.'

(105) Najzimniejszy miesiąc to jest styczeń.

coldest.NOM month.NOM TO be.PRES.3SG January.NOM

'January is the coldest month.'

As for (104), up to a point represented by stage (106) the derivation may be argued to mirror that for copular-to clauses:

(106) [DP2[DP1 Janek][DP2[DP1 1 DP2 harcerz]]]

At this stage, an option of merging the $\mathrm{DP}_{2}$ in (106) with a verbal copula jest ('is') is selected. The verbal copular is thought of as an instance of a raising (linking) verb selecting a nominal SC as complement. The verb is tensed which entails a further merger with a functional head T equipped with the EPP feature which triggers the Internal Merge of Janek in Spec.TP, resulting in (107):

(107) [TP [DPJanek] [T T [vP [v jest] [DP2 [DP1 harcerz]]]]]]

Next, the TP in (107) merges with a predicate head to and the further steps of the derivation are the same as for the cases of predicational copular-to clauses, leading to the formation of (108):

40 The reviewer asks why it cannot be the other way round, i.e. "why couldn't $\mathrm{DP}_{1}$ be Focus (Predicate) and $\mathrm{DP}_{2}$ Topic (Subject of Predication)". This would be possible as an instance of ex situ focus, not specifically addressed in this paper:

(i) Najzimniejszy MIESIĄC to styczeń.

Coldest.NOM month.NOM.FOC TO styczeń.NOM

'January is the coldest MONTH.'

Examples like (i) show the importance of the interaction of the placement of focal stress with Internal Merge and information structure, as widely discussed in the literature (e.g. Bresnan 1971; Selkirk 1984; Zubizarreta 1998; Reinhart 2006, Adger 2007). In this paper we consider the cases when focus is not shifted, i.e. it falls on the most embedded constituent in accordance with NSR (Nuclear Stress Rule, as originally formulated by Halle \& Vergnaud 1987, and then revised by Cinque 1993, Zubizarreta \& Vergnaud 2005). 
(108) [sPredP [DP Janek][sPred [sPred to] [TP [DP1Janek] [т T [vP [v jest] [DP2 [DP1 anek] [DP2[DP1 [DP2 harcerz]]]]]]]]]

\section{Advantages of the proposal}

The foregoing analysis of predicational and specificational copular-to sentences has a few important advantages over the three accounts presented earlier. With respect to Rutkowski's (2006) proposal, it avoids the problem with the $\theta$ identification of the higher of the two NPs (DPs) in a structure of copular-to clauses; such a phrase first appears in a $\theta$ position of a PredP (SC). Next, if to is not a resumptive pronoun identifying a topic, but a predicate head, the problem of the possible co-occurrence with another resumptive pronoun identifying a topic in left-dislocation structures disappears.

Furthermore, the present approach allows to avoid some inconsistencies arising from the treatment of to być and pure to as the two variants related merely by być deletion in cases involving the present tense, as postulated in Rutkowski's (2006) and Bondaruk's (2013) accounts. Such a deletion creates a problem if być is a head of $\mathrm{VP}$ or $\mathrm{vP}$ and the process is to occur in syntax - it would make these projections headless. If the dropping of byc is a matter of PF, as suggested by Bondaruk (2013), then syntactic information about the type of tense must be recovered at PF. Under our analysis, such an unwanted recovery of syntactic information at $\mathrm{PF}$ is avoided as there is no dropping of być; the derivation may include a stage at which an SC is merged with być, leading to the formation of a to być-copular clause, or such a stage may be excluded which results in the formation of a to-copular clause.

As compared with Citko's (2008), the present proposal avoids a problem with the restriction on the appearance of a null version of a defective instance of a predicator head $(\pi)$ to the present tense by postulating there is no null version of a defective predicate. Further, here is how the present approach explains a possible lack of agreement in number (and gender) between the two DPs (NPs) in copularto clauses. In the present analysis such sentences are derived from small clauses. At the stage at which an SC is formed, as a result of symmetry breaking, there is no $\varphi$ feature checking by a head external to SC. Rather, there is an instance of Subject-Predicate Noun agreement like in John is a scout, Children are our future, or Rats are a subgroup of rodents. This form of agreement appears to be conditioned semantically; a mismatch in formal features is allowed for some classes of nouns, e.g. abstract, mass nouns or nouns denoting groups or categories. It is not allowed for other kinds of nouns, though, e.g. countable nouns, as in *John is scouts, etc. It appears there is no use trying to determine SC-internal agreement with reference to $\varphi$ feature checking or sharing because such an account would have to anyhow refer to semantic constraints on number (and gender). 
A different but related problem is the necessary agreement of the verb byc ('be') in to być copular clauses with the second DP (NP), unexplained in Citko's (2008) proposal, as in (109) below:

(109) [Ci czterej piłkarzepluR] to jestsing/*sąpLuR [najlepsza obrona w lidzesing].

these four players to is/*are best defence in league

'These four players are the best defence in the league.'

In the account advocated here there is no need to recourse to a dedicated rule like "In to być-copular clauses it is the second DP which determines concord in with the verb", as proposed by Rutkowski (2006). Instead, it is assumed that with the insertion of the raising verb which carries a set of un-interpretable, un-valued $\varphi$ features, the relation Agree is immediately established between the verb (probe) and its complement DP (SC) (goal), as schematically presented in (110) below: ${ }^{41}$ (110)

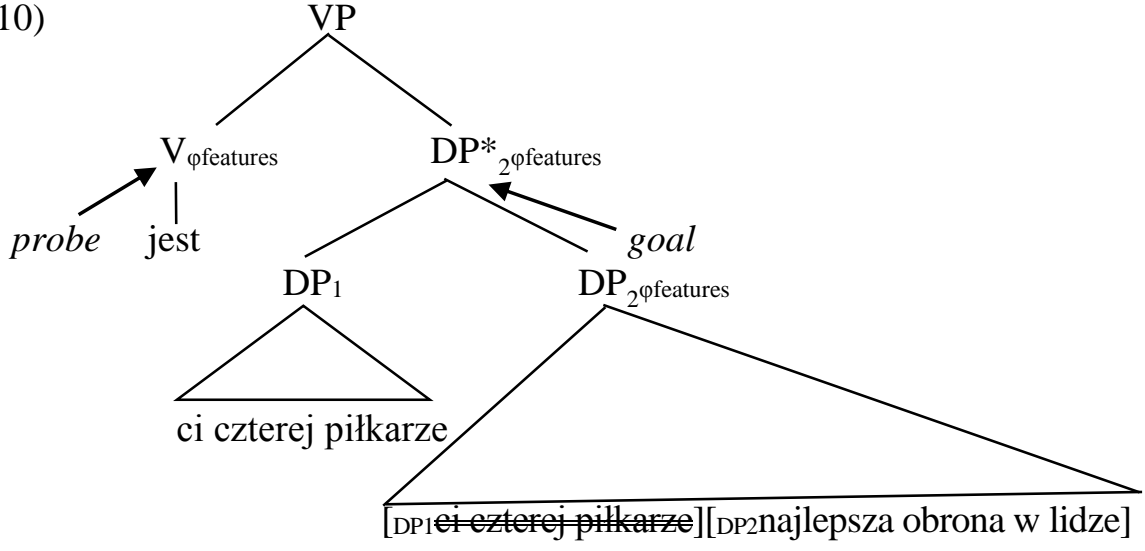

As discussed earlier (example (72)), $\mathrm{DP}_{2}$ is formed by (free) spontaneous symmetry breaking. Because it is the $\varphi$-features of $\mathrm{DP}_{2}$ that percolate to $\mathrm{DP}_{2}$,

41 There is a significant limitation, noted by Rutkowski (2006) and mentioned also by the anonymous reviewer, of the prediction that there is always concord of the verb with the second DP in to być copular clauses: the agreement in question is limited to the features [number] and [gender], but excludes [person]. Thus, examples like (i) appear counterfactual to both the dedicated rule proposed by Rutkowski (2006) and to the present account:
(i)

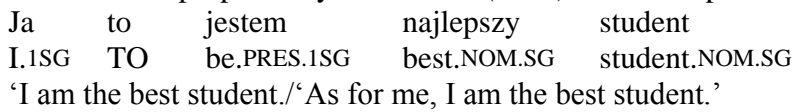

As a way of adapting our account to this restriction, we make a tentative assumption that a set of un-interpretable, un-valued features carried by the verb jest ('is') is defective (lacks a [person] feature). 
the Agree relation is established by the verb with $\mathrm{DP}_{2}$ (i.e. a Predicate) and not with $\mathrm{DP}_{1}$, hence agreement of the verbal copula with the DP on the right. Later, $\mathrm{DP}_{1}$ is raised to Spec. VP, then to Spec. Pred.P, and ultimately lands on the left side of $t o$. Thus, agreement with the second DP comes out in the most natural way as an outcome of the proposed derivation. ${ }^{42}$

A valid critical point raised by the anonymous reviewer with respect to the above proposal is that it cannot be claimed to be a better solution than Rutkowski's (2006) rule if it does not account for the situation in English in which agreement has to always hold with the first, not second DP. This is true and the contrast deserves a thorough examination, which is beyond the scope of the present paper. Tentatively, it may be suggested that the source of the contrast may be the defective status of $\mathrm{T}$ in Polish to być-copular clauses vs. a nondefective status of $\mathrm{T}$ in English be-copular sentences. If this difference holds, then for Polish to być-copular clauses the number and gender features of a DP are checked only against a V head, as given in (110) above. In English, in turn, the $\mathrm{T}$ is equipped with a complete set of $\varphi$-features and the probing relation can hold between $\mathrm{T}$ and $\mathrm{DP}_{1}$, as soon as $\mathrm{DP}_{1}$ gets out of the $\mathrm{DP}_{2}{ }^{43}$

With respect to Bondaruk's (2013) analysis, the placement of wh-phrases between to and jest ('is'), like in (69) above, may be explained by the presence of a ForceP or FinP position above TP and below Pred.P, as in (111) below:

(111) [SPredP [sPred to [Force/FinP wh [TP jest ... ]]]]]]

The configuration in (111) is an option in which "more structure" needed for wh-checking is derived above TP before the phrase merges with a Pred. head to. Such a solution would not be possible in Bondaruk's structure in which to is raised by clitic climbing to $\mathrm{T}$. Likewise, the presence of a sentence adverb (e.g. zapewne ('certainly')) after to in constructions without a copular verb, as in (68) above, finds an account in (112):

\section{(112) [DP2 adverb[DP2[DP1 Janek][DP2[DP1 Janek] [DP2 harcerz]]]]}

The adverb is adjoined (by pair-Merge) to DP in (112), prior to the merger with to. Next, after DP raising to Spec. SPred.P structure (113) is formed, with the adverb positioned in between to and the second DP:

42 Note that the same mechanism would apply to the inverted example: [Najlepsza obrona w

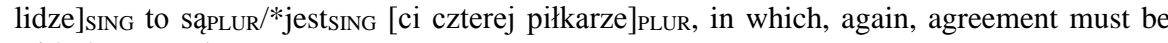
with the second DP.

43 For English, it would have to be determined which position $\mathrm{DP}_{1}$ can occupy in the ccommand domain of T. A plausible option is Spec. vP, if there is a $v$ in the structure of English copular sentences, as proposed by Mikkelsen (2005b). 
(113) [SPredP2 Janek [SPred to[DP2 $a d v e r b[\mathrm{DP} 2[\mathrm{DP} 1$ Janek][DP2[DP1 Janek] [DP2 harcerz]]]]]]

Such a placement of the adverb would not be possible under Bondaruk's (2013) account in which to takes the second DP alone as complement. ${ }^{44}$

Moreover, the present account avoids a range of problems arising from treating to in structures different from to-copular clauses as a pure emphatic marker. First, unlike Bondaruk's (2013), it explains why outside of copular clauses to appears only in sentence-initial or sentence-second positions. If to was an emphatic marker it should be freely attachable to phrases in different places (as focus particles only, even, also are), but as a Pred head it is tied to one position, with a possible re-Merge in the front of the clause, as discussed in 3.3.1. Next, a problem with cases in which to is argued to be clitic-climbed to a preverbal position if there is no verb in the structure (it has been dropped) is avoided. Finally, the lack of the co-occurrence of the allegedly emphatic to in to-clefts with a copular to is explained under the unitary approach to both occurrences of to, advocated here.

Finally, a point in favour of the approach proposed here may be derived from the syntax of Polish appositive constructions of the form [DP DP], as exemplified by (114) below:
(114) Janek harcerz
to nie ta sama
osoba
co
Janek kibic piłkarski.
John.NOM scout.NOM TO not this same.NOM person.NOM what John.NOM fan.NOM football
'John, the scout is not the same person as John, the football fan.'

Unlike the other approaches considered here, in our account there is a stage in the derivation of copular clauses at which the two DPs exhaustively form as a separate constituent, as exemplified by (90), repeated below. Such a constituent can be used as an appositive in typical DP locations.

\section{[DP2[DP1 Janek][DP2[DP1 $]$ [DP2 harcerz]]]}

As noted by the reviewer, the matter needs more examination, but a syntactic construct in (90) appears a good candidate for the representation of the appositive DP.

\footnotetext{
44 We assume that sentence adverbs can modify propositions, hence may be adjoined to DPs if these are small clauses, but not to single DPs.
} 


\section{Conclusion and suggestions for possible extension}

The foregoing proposal has been meant to contribute to a current discussion on the structure and derivation of non-verbal copular constructions in Polish. There are a few ways in which it has differed from the previous accounts of a similar range of syntactic facts. First, it ascribes to the particle to the status of a head of a new type of predication, called Specification Predication, which, along the lines suggested by Kiss (2006, 2010), provides a syntactic basis for the interpretation of focus. When to is merged in a structure with two nominal phrases arranged as a small clause, the nominal phrase designated as the Subject of Predication internally merges with a projection of to, forming a construct like (115):

\section{(115) $\left[\mathrm{DP}_{1}\left[\right.\right.$ to $\left.\left.\left[\mathrm{PP}_{1}\left[\mathrm{PP}_{1} \mathrm{DP}_{2}\right]\right]\right]\right]$}

Structure (115) underlines a copular-to clause syntactically, but it also serves as a basis for a discourse-relevant Topic-Focus partition; an element c-commanded by to, i.e. $\mathrm{DP}_{2}$ is the value of specification (it is a specification predicate) and interpreted as a kind of focus, while $\mathrm{DP}_{1}$ is a topic (and subject of specification predication) ${ }^{45}$

The proposal is consistently derivational and it offers a unitary treatment of the two types of copular-to clauses (predicational and specificational). The issue requires much further investigation, but the proposed analysis seems to have the potential for extension to two other syntactic types in Polish featuring the occurrence of to, namely to-clefts and topic-to sentences, occasionally referred to in this paper. Such an extension can be left for another study, but it may at least be speculated that if it proves valid then some generalized unitary structure like (116) below, might be proposed for all of these syntactic types: ${ }^{46}$

\section{(116) $[$ sPredP XP [sPred [sPred $t o]\left[\right.$ YP...]]] where YP: $\{\mathrm{DP}, \mathrm{TP}, \text { Force/FinP }\}^{47}$}

45 The reviewer notes that right after the merger of to more than one element is c-commanded by $t o$, hence it is unclear which is to be interpreted as focus. But, the merger of to is immediately followed by the Internal Merge of one of the DPs in Spec. Pred.P (due to EPP). Hence, at an interpretive stage (transfer to SEM), there is just one DP left in the c-command domain of $t o$.

46 As noted earlier, a detailed proposal of the account of topic-to and to-clefts in Polish in terms unitary with the present analysis of copular-to clauses has been offered in a separate study (Tajsner forthcoming). As also noted by the anonymous reviewer of this paper, to hold also for a to-cleft, the structure in (116) would have to additionally account for the fronting of to. Tajsner (forthcoming) argues that the fronting of to is a result of a reprojective re-Merge of $t o$, a free derivational option, along the lines of e.g. Donati (2006), Boeckx (2008), Roberts (2011) or Citko (2011), resulting in: [ Pred to [PredP XP [Pred [Pred $€$ ] [YP...]]]]. For details see Tajsner (forthcoming).

47 The anonymous reviewer notes that there is a problem with structure (116) when applied to 


\section{REFERENCES}

Adger, David. 2007. Stress and phasal syntax. Linguistic Analysis 33(3-4). 238-266.

Armstrong, Lilias E. \& Ida C. Ward. 1926. A handbook of English intonation. Cambridge: Heffer. Balazs, Julie Elizabeth. 2012. The syntax of small clauses. Unpublished M.A. thesis. Cornell University.

Boeckx, Cedric. 2008. Bare syntax. Oxford: Oxford University Press.

Bondaruk, Anna. 2013. Copular clauses in English and Polish: Structure, derivation, and interpretation. Lublin: Wydawnictwo KUL.

Bošković, Željko. 2008. What will you have, DP or NP? In Emily Elfner \& Martin Walkow (eds.), Proceedings of the North East Linguistic Society 37: University of Illinois at Urbana-Champaign, 101-114. Amherst, MA: GLSA.

Bošković, Željko. 2012. On NPs and clauses. In Günther Grewendorf \& Thomas E. Zimmermann (eds.), Discourse and grammar: From sentence types to lexical categories (Studies in Generative Grammar 112), Berlin: Mouton de Gruyter. 179-242.

Bošković, Željko \& Jon Gajewski. 2011. Semantic correlates of the NP/DP parameter. In Suzi Lima, Kevin Mullin \& Brian Smith (eds.), Proceedings of the 39th annual meeting of the North East Linguistic Society: Cornell University, 121-134. Amherst, MA: GLSA.

Bowers, John. 1993. The syntax of predication. Linguistic Inquiry 24(4). 591-656.

Bowers, John. 2003. Predication. In Mark Baltin \& Chris Collins (eds.), Handbook of contemporary syntactic theory (Blackwell Handbooks in Linguistics), 299-333. Oxford: Blackwell Publishing.

Bresnan, Joan. 1971. Sentence stress and syntactic transformations. Language 47(2). 257-281.

Campbell, Richard. 1996. Specificity operators in SpecDP. Studia Linguistica 50(2). 161-188.

Chomsky, Noam. 1995. The minimalist program (Current Studies in Linguistics 28). Cambridge, MA: MIT Press.

Chomsky, Noam. 2004. Beyond explanatory adequacy. In Adriana Belletti (ed.), Structures and beyond: The cartography of syntactic structure. Vol. 3 (Oxford Studies in Comparative Syntax), 104-131. Oxford: Oxford University Press.

Chomsky, Noam. 2008. On phases. In Robert Freidin, Carlos P. Otero \& Maria Luisa Zubizaretta (eds.), Foundational issues in linguistic theory: Essays in honor of Jean-Roger Vergnaud, 133-166. Cambridge, MA: MIT Press.

Polish to-clefts in that to c-commands the entire PredP, which should then all be interpreted as a focus phrase. But, in cases like (i) below:
(i)

$\begin{array}{llll}\text { To } & \text { MAREK } & \text { zdał } & \text { egzamin } \\ \text { TO } & \text { Marek.NOM.FOC } & \text { pass.PST.3SG.M } & \text { exam.ACC }\end{array}$
'It was Marek who passed the exam.'

only the nominative subject is interpreted as focus. A way to deal with such cases proposed by Tajsner (forthcoming) is by assuming that to is a Pred head whose appearance in the structure triggers a need for predicate saturation. Thus, its appearance entails that some element has to merge in the Spec. PredP. An instance in (i) is a case when the subject carrying focal stress merges in Spec. PredP, as an option. But, to functions also as a probe equipped with an unvalued, interpretable feature [+Specification] which has to be matched with a ccommanded goal carrying focal stress. This calls for an instance of re-Merge of $t o$, resulting in structure [ Pred to [PredP XP [Pred [Pred $€$ ] [YP...]]] (see note 45 above). Thus, in (i) above, the nominative subject is singled out in a Spec.Pred.P position, and is minimally searched for by $t o$, instead of the whole PredP. 
Chomsky, Noam. 2013. Problems of projection. Lingua 130. 33-49.

Cinque, Guglielmo. 1993. A null theory of phrase and compound stress. Linguistic Inquiry 24(2). 239-297.

Citko, Barbara. 2008. Small clauses reconsidered: Not so small and not all alike. Lingua 118(3). 261-295.

Citko, Barbara. 2011. Symmetry in syntax: Merge, move, and labels (Cambridge Studies in Linguistics 129). Cambridge \& New York: Cambridge University Press.

Dikken, Marcel den. 2006. Relators and linkers: The syntax of predication, predicate inversion, and copulas (Linguistic Inquiry Monographs 47). Cambridge, MA: MIT Press.

Donati, Caterina. 2006. On wh-head movement. In Lisa Lai Shen Cheng \& Norbert Corver (eds.), Wh-movement: Moving on (Current Studies in Linguistics 42), 21-46. Cambridge, MA: MIT Press.

Enç, Mürvet. 1991. The semantics of specificity. Linguistic Inquiry, 22(1). 1-25.

Frajzyngier, Zygmunt. 1993. A grammar of Mupun (Sprache und Oralität in Afrika 14). Berlin: Dietrich Reimer.

Frampton, John \& Sam Gutmann. 2002. Crash-proof syntax. In Samuel David Epstein \& T. Daniel Seely (eds.), Derivation and explanation in the minimalist program (Generative Syntax 6). 90-105. Malden, MA: Blackwell Publishers.

Geist, Ljudmila. 2007. Predication and equation in copular sentences in Russian vs. English. In Ileana Comorowski \& Klaus von Heusinger (eds.), Existence: Semantics and syntax (Studies in Linguistics and Philosophy 84), 79-105. Dordrecht: Springer.

Green, Melanie. 2007. Focus in Hausa (Publications of the Philological Society 40). Oxford: Blackwell Publishing.

Hale, Kenneth L. \& Jay Keyser. 2002. Prolegomenon to a theory of argument structure (Linguistic Inquiry Monographs 39). Cambridge, MA: MIT Press.

Halle, Morris \& Jean-Roger Vergnaud. 1987. An essay on stress (Current Studies in Linguistics 15). Cambridge, MA: MIT Press.

Heggie, Lorie, A. 1988. The syntax of copular clauses. Unpublished Ph.D. dissertation, University of South California.

Heusinger, Klaus von. 2002. Specificity and definiteness in sentence and discourse structure. Journal of Semantics 19(3). 254-274.

Heycock, Caroline \& Anthony Kroch. 1999. Pseudocleft connectedness: Implications for the LF interface level. Linguistic Inquiry 30(3). 365-397.

Higgins, Roger. 1973. The pseudo-cleft construction in English. Unpublished Ph.D. dissertation, MIT.

Higgins, Roger. 1979. The pseudo-cleft construction in English (Outstanding Dissertations in Linguistics). New York: Garland.

Hornstein, Norbert. 2009. A theory of syntax: Minimal operations and Universal Grammar. Cambridge \& New York: Cambridge University Press.

Huber, Christian. 1999. Issues in syntax and interpretation of Sumerian clauses. In Jeremy Black \& Gábor Zólyomi (eds.), Proceedings of Workshop on Diachronic and Synchronic Variations in the Phonology, Morphology, and Syntax of Sumerian, (no pages). Oxford: Oriental Institute.

Huber, Stefan. 2002. Es-Clefts und det-Clefts: Zur Syntax, Semantik und Informationsstruktur von Spaltsätzen im Deutschen und Schwedischen (Lunder Germanistische Forschungen 64). Stockholm: Almquist \& Wiksell International. 
Kiss, Katalin É. 2006. Focussing as predication. In Valéria Molnár \& Susanne Winkler (eds.), The architecture of focus (Studies in Generative Grammar 82), 193-193. Berlin: Mouton de Gruyter.

Kiss, Katalin É. 2010. Structural focus and exhaustivity. In Malte Zimmermann \& Caroline Féry (eds.), Information structure: Theoretical, typological and, experimental perspectives, 64-88. Oxford: Oxford University Press.

Kohler, Klaus J. 2006. What is emphasis and how is it coded? In Rüdiger Hoffmann \& Hansjörg Mixdorff (eds.), Speech prosody: 3rd International Conference, Dresden, May 2-5, 2006, 748-751. Dresden: TUDpress.

Koopman, Hilda \& Dominique Sportiche. 1991. The position of subjects. Lingua 85(2-3). 211258.

Linde-Usiekniewicz, Jadwiga. 2007. Small clauses reconsidered revisited: Not so small and not all alike, and far fewer. Lingua Posnaniensis 49. 83-91.

Linde-Usiekniewicz, Jadwiga \& Paweł Rutkowski. 2006. NP coordination as a new argument in the debate on the DP-analysis of Polish. In Blake H. Rodgers (ed.), Proceedings of WIGL 2006 (LSO Working Papers in Linguistics 6), 103-117.

Mikkelsen, Line. 2005a. Copular clauses: Specification, predication and equation (Linguistik Aktuell 85). Amsterdam: John Benjamins.

Mikkelsen, Line. 2005b. Subject choice in copular clauses. Unpublished MS, UC Berkeley.

Moro, Andrea. 1997. The raising of predicates: Predicative noun phrases and the theory of clause structure (Cambridge Studies in Linguistics 80 ). Cambridge: Cambridge University Press.

Moro, Andrea. 2000. Dynamic antisymmetry (Linguistic Inquiry Monographs 38). Cambridge, MA: MIT Press.

Moro, Andrea. 2008. The boundaries of Babel: The brain and the enigma of impossible languages (Current Studies in Linguistics 46). Cambridge, MA: MIT Press.

Pereltsvaig, Asya. 2001. On the nature of intra-clausal relations. Unpublished Ph.D. dissertation, McGill University.

Pereltsvaig, Asya. 2007. Copular sentences in Russian. A theory of intra-clausal relations (Studies in Natural Language and Linguistic Theory 70). Dordrecht: Springer.

Prince, Ellen F. 1981. On the inferencing of indefinite-this NPs. In Aravind K. Joshi, Bonnie L. Weber \& Ivan A. Sag (eds.), Elements of discourse understanding, 231-250. Cambridge \& New York: Cambridge University Press.

Progovac, Ljiljana. 2010. Syntax: Its evolution and its representation in the brain. Biolinguistics. 4.(2-3). 234-254.

Rappaport, Gilbert C. 2001. Extraction from nominal phrases and the theory of determiners. In Ewa Willim \& Piotr Bański (eds.), Formal approaches to Polish syntax, 159-198. Bloomington, IN; Slavica Publishers.

Reinhart, Tanya. 2006. Interface strategies. Optimal and costly computation (Linguistic Inquiry Monographs 46). Cambridge, MA: MIT Press.

Rizzi, Luigi. 2006. "On the form of chains: Criterial positions and ECP effects. In Lisa Lai Shen Cheng \& Norbert Corver (eds.), Wh-movement: Moving on (Current Studies in Linguistics 42), 97-134. Cambridge, MA: MIT Press.

Roberts, Ian. 2011. Head movement and the Minimalist Program. In Cedric Boeckx (ed.), The Oxford handbook of linguistic Minimalism (Oxford Handbooks in Linguistics), 195219. Oxford: Oxford University Press. 
Roy, Isabelle. 2006. Non-verbal predication: A syntactic analysis of predicational copular sentences. Unpublished Ph.D. thesis, University of Southern California.

Rutkowski, Paweł. 2006. From demonstratives to copulas: A cross-linguistic perspective and the case of Polish. Journal of Universal Language 7. 147-173.

Selkirk, Elizabeth O. 1984. Phonology and syntax: The relation between sound and structure (Current Studies in Linguistics 10). Cambridge, MA: MIT Press

Sharvit, Yael. 1999. Connectivity in specificational sentences. Natural Language Semantics 7(3). 299-339.

Stowell, Tim. 1981. Origins of phrase structure. Unpublished Ph.D. thesis, MIT.

Tajsner, Przemysław. 2008. Aspects of the grammar of focus: A minimalist view (Polish Studies in English Language and Literature 24). Frankfurt am Main: Peter Lang.

Tajsner, Przemysław. forthcoming. On focus marking and predication. Evidence from Polish with some notes on Hausa. Lingua Posnaniensis.

Wedgwood, Dan. 2003. Predication and information structure. A dynamic account of the Hungarian pre-verbal system. Unpublished Ph.D. thesis: University of Edinburgh.

Wedgwood, Dan. 2006. Predication, focus and the positions of negation in Hungarian. Lingua 116(3). 351-376.

Williams, Edwin. 1983. Semantic vs. syntactic categories. Linguistics and Philosophy 6(3). 423446.

Willim, Ewa. 2000. On the grammar of Polish nominals. In Roger Martin, David Michaels, \& Juan Uriagereka (eds.), Step by step: Essays on minimalist syntax in honor of Howard Lasnik, 319-346. Cambridge, MA: MIT Press.

Witkoś, Jacek. 1998. The syntax of clitics. Steps towards a minimalist account. Poznań. Motivex.

Zubizarreta, Maria Luisa. 1998. Prosody, focus, and word order (Linguistic Inquiry Monographs 33). Cambridge, MA: MIT Press.

Zubizarreta, Maria Luisa \& Jean-Roger Vergnaud. 2005. Phrasal stress, focus, and syntax. In Martin Everaert \& Henk C. van Riemsdijk (eds.), The Blackwell companion to syntax. Vol. 3 (Blackwell Handbooks in Linguistics 19), 522-568. Cambridge: Blackwell Publishing. 